NADEJDA MARIA ÁVILA VARGINHA DE MORAES E SILVA

\title{
Estudo da ação do nível elevado de pressão sonora e do extrato seco de Ginkgo biloba EGb761 na citoarquitetura da cóclea de cobaias adultas
}

Tese apresentada ao Departamento de Oftalmologia e Otorrinolaringologia da Faculdade de Medicina da Universidade de São Paulo para obtenção do título de Doutor em Ciências.

Área de Concentração: Otorrinolaringologia Orientadora: Prof Dra. Roseli Saraiva Moreira Bittar

São Paulo 2005 
FICHA CATALOGRÁFICA

Preparada pela Biblioteca da

Faculdade de Medicina da Universidade de São Paulo

Silva, Nadejda Maria Ávila Varginha de Moraes e

Estudo da ação do nível elevado de pressão sonora e do extrato seco de Ginkgo biloba EGb761 na citoarquitetura da cóclea de cobaias adultas /

Nadejda Maria Ávila Varginha de Moraes e Silva. -- São Paulo, 2005.

Tese (doutorado)--Faculdade de Medicina da

Universidade de São Paulo.

Departamento de Oftalmologia e Otorrinolaringologia.

Área de concentração: Otorrinolaringologia.

Orientadora: Roseli Saraiva Moreira Bittar.

Descritores: 1.EFEITOS DO RUÍDO 2.POLUIÇÃO SONORA 3.PERDA AUDITIVA PROVOCADA POR RUÍDO 4.GINKGO BILOBA/uso terapêutico 5.CÓCLEA/efeitos de drogas 6.COBAIAS 7.MICROSCOPIA ELETRÔNICA DE VARREDURA/métodos 
Dedico esta tese

Aos meus pais Jonas e Lea pelo exemplo de vida, amor e incentivo incondicionais. Por me mostrarem que a vida vale a pena quando é simples e se houver amor no coração.

Aos meus irmãos e sobrinhos, estruturas vivas de sustentação dos meus sonhos.

Ao meu marido, Evandro e às nossas filhas, Carolina Beatriz e Isabela,por significarem a luz divina presente em minha vida. 
À Profa. Dra Roseli Saraiva Moreira Bittar, orientadora incansável deste trabalho, por sua competência, sensibilidade e determinação. Exemplo de seriedade e disciplina, a ser seguido na vida acadêmica. 


\section{AGRADECIMENTOS}

Desejo agradecer

Ao Prof Dr Ricardo Ferreira Bento, chefe da Otorrinolaringologia do Departamento de Oftalmologia e Otorrinolarongologia da Faculdade de Medicina da USP por ter me aceitado no programa de pós-graduação, criando condições para a realização deste trabalho.

À Dra. Tanit Ganz Sanches e ao Dr. Marco Aurélio Bottino, por terem feito parte da minha trajetória na Faculdade de Medicina da Universidade de São Paulo FMUSP, como primeiros orientadores e incentivadores.

Ao Dr José Tarcísio Cavaliere, diretor do Curso de Medicina do Centro Universitário de Volta Redonda - UNIFOA, pelo apoio incondicional, permitindo a utilização das dependências físicas e a colaboração dos funcionários da instituição durante toda a realização do trabalho.

À Dra. Renata Braga da Graça e à Dra. Elizabeth Carolina Mathias de Araújo, professoras auxiliar e assistente da Disciplina de Otorrinolaringologia do Curso de Medicina do UNIFOA pelo incentivo, amizade e apoio, permitindo que eu dedicasse mais tempo para a conclusão deste trabalho.

À Dra Loreley Andrade Luderer, professora titular da Disciplina de Patologia do Curso de Odontologia do UNIFOA, por sua generosidade, seriedade e profissionalismo na realização da microscopia de luz em todas suas etapas.

À Dra Vera Cristina Marczuk, médica veterinária, ao sr. Florisval Ignácio Teixeira, funcionário, responsáveis pela manutenção dos animais do UNIFOA 
Ao Hospital Vita Volta Redonda, na pessoa de seu diretor médico, Dr José Mauro Rezende, pelo empréstimo do microscópio cirúrgico.

Ao Dr Ricardo de Mattos Santa-Rita, biólogo da Fundação Oswaldo Cruz FIOCRUZ e professor da Disciplina de Histologia do Curso de Medicina do UNIFOA, pelo constante apoio e pela realização da microscopia eletrônica de varredura.

Às sras. Andréa Auad e Luciana Cardoso, fonoaudiólogas, responsáveis pela realização das otoemissões acústicas de Volta Redonda - RJ.

Ao sr. Anderson José Aparecido e sr. Lourival Dias Pereira, técnicos do Laboratório de Cirurgia Experimental do Curso de Medicina do UNIFOA, pela dedicação, companheirismo, profissionalismo e incentivo, prestados nas etapas experimentais deste trabalho.

Ao sr. Jorge Anderaus pela adaptação da sirene piezoelétrica à câmara acústica Telex do Brasil, no município de Volta Redonda - RJ, por ceder a câmara acústica semi-anecóica e ao sr. Paulo de Oliveira Simeão, engenheiro de segurança do trabalho, responsável pela avaliação técnica da câmara acústica e da sirene piezoelétrica.

À Dra Débora Shiota, médica, e ao sr. Carlos Alberto D’Avila, representante responsável pela linha “Tebonin” do Laboratório ALTANA PHARMA, pelo apoio à pesquisa realizada e pela doação da droga utilizada.

Na FIOCRUZ, à Dra. Helene Santos Barbosa, bióloga e pesquisadora, à sra. Suzana Corte Real, chefe de departamento de Ultra Estrutura e Biologia Celular e à sra. Kelly Salomão, pela realização da microscopia eletrônica de varredura.

À Dra Norma Tognon Pedra Ferreira e à Dra Maria Elisa Cunha Ramos, companheiras de jornada e incentivadoras de minha vida acadêmica. 
À Dra Maria Cecília Lorenzi, pelo apoio nos momentos difíceis e pela análise estatística dos resultados.

Ao Dr Edigar Resende de Almeida e ao Dr Ossamu Butugan, mestres na ciência do viver, na sabedoria do aprender sempre e no amor à arte da medicina.

Ao Dr Idemar Monteiro da Palma, companheiro constante e incentivador incondicional de minha vida acadêmica.

Ao Dr João Paulo do Val, pelo empréstimo do Decibelímetro e pelo apoio às etapas da validação técnica dos aparelhos utilizados no estudo.

Às secretárias do Serviço de Otorrinolaringologia e da Pós-Graduação do HCFMUSP, sras. Marilede, Márcia, Lucy, Bárbara e Edizira, pelo carinho e atenção recebidos.

Aos srs. Agessandro Abrahão Júnior e Samuel Valença pelo apoio na pesquisa histológica, pelos esforços incansáveis em solucionar dificuldades e pelo espírito científico que os anima.

À Dra Janete Mostaro de Aguiar Campos, amiga de todos os momentos, pela realização das fotografias e total apoio durante o trabalho.

À Dra Carolina Ávila Varginha de Moraes e Silva e à srta. Isabela Ávila Varginha de Moraes e Silva pela participação ativa, pela solidariedade e espírito científico em todos os momentos deste trabalho. 


\section{SUMÁRIO}

Lista de abreviaturas

Lista de Figuras

Lista de Tabelas

Resumo

Summary

1. INTRODUÇÃO

2. OBJETIVO

3. REVISÃO DA LITERATURA …................................................ 24

3.1. Ação do ruído na cóclea ............................................................. 25

3.2. Estudo estrutural da cóclea sob ação do ruído .......................... 27

3.2.1 Microscopia de luz .................................................... 27

3.2.2 Microscopia eletrônica de varredura ............................... $\quad 30$

3.3 Emissões otoacústicas no ruído experimental ........................... 32

3.4 Drogas otoprotetoras .......................................................... 33

3.5 Mecanismo da ação do extrato seco de Ginkgo biloba Egb 761. 34

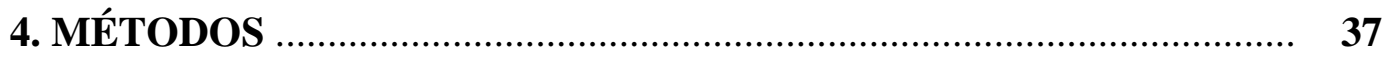

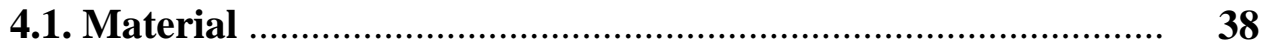

4.1.1 Amostra ................................................................. 38

4.1.2 Otoemissões Acústicas ................................................. 39

4.1.3 Critérios de inclusão ....................................................... 39

4.1.4 Critérios de exclusão ................................................... 40

4.1.5 Formação dos Grupos ................................................ $\quad 40$

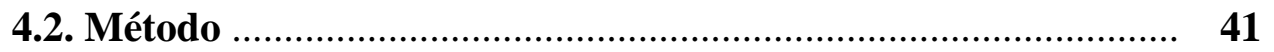

4.2.1 Droga de estudo ......................................................... 42

4.2.2 Estímulo sonoro ......................................................... 42

4.2.3 Retirada dos Ossos Temporais ..................................... 44

4.2.4 Avaliação da Citoarquitetura da Cóclea .......................... 46 
4.3.1 Cálculo da amostra .................................................. 49

4.3.2 Metodologia estatística .............................................. 49

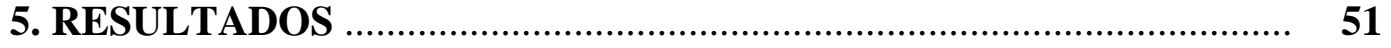

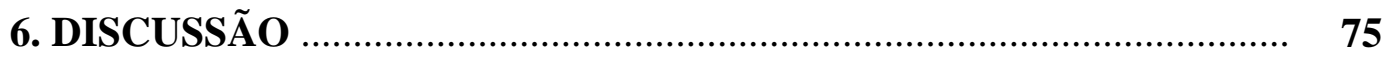

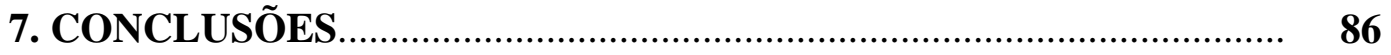

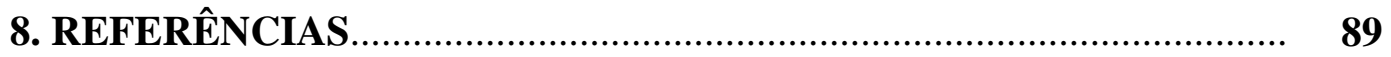

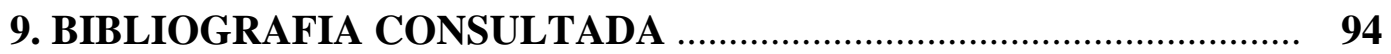




\section{LISTA DE ABREVIATURAS}

\begin{tabular}{|c|c|}
\hline $\mathrm{dB}(\mathrm{A})$ & - decibel (Acústico) \\
\hline EDTA & $\begin{array}{l}\text { - Ethylenediamine tetraacetic acid (ácido etilenodiamino tetra } \\
\text { acético) }\end{array}$ \\
\hline EGb & - Extrato de Ginkgo biloba \\
\hline EOAPD & - Emissões Otoacústicas por Produto de Distorção \\
\hline FIOCRUZ & - Fundação Instituto Oswaldo Cruz \\
\hline Gc & - Grupo controle \\
\hline Gegb & - Grupo extrato seco de Ginkgo biloba \\
\hline Gegb+r & - Grupo extrato seco de Ginkgo biloba com exposição ao ruído \\
\hline Ger & - Grupo exposto ao ruído \\
\hline $\mathrm{HE}$ & - Hematoxilina-eosina \\
\hline $\mathrm{ME}$ & - Microscopia Eletrônica \\
\hline MEV & - Microscopia Eletrônica de Varredura \\
\hline $\mathrm{NIOSH}$ & - National Institute for Occupational Safety and Health \\
\hline NMDA NR1 & - receptores glutamatérgicos N-metil-D-aspartato NR1 \\
\hline OEA & - Otoemissões acústicas \\
\hline $\mathrm{ONOO}^{-}$ & - ánion peroxinitrito \\
\hline $\mathrm{OsO}_{4}$ & - tetróxido de ósmio \\
\hline PAINPS (E) & - Perda Auditiva Induzida por Pressão Sonora (Elevada) \\
\hline PTS & - Permanent Treshold Shift (perda auditiva permanente) \\
\hline SPL & - Sound Pressure Level (nível de pressão sonora) \\
\hline TTS & - Temporary Treshold Shift (perda auditiva temporária) \\
\hline & - Centro Universitário Fundação Oswaldo Aranha \\
\hline
\end{tabular}




\section{LISTA DE FIGURAS}

Figura 1 Cobaia posicionada na câmara acústica para receber estímulo sonoro

Figura 2 Cronograma do trabalho experimental

Figura 3 Porcentagem de animais com congestão capilar na estria vascular em intensidade discreta, moderada e acentuada, nos grupos Gc, Gr e Gegb+r

Figura 4 Porcentagem de animais com alterações no órgão de Corti, discretas, degenerativas e destrutivas, nos grupos Gc, Gr e Gegb+r.

Figura 5 Porcentagem de animais que apresentou alterações na membrana vestibular, nos grupos Gc, Gr e Gegb+r

Figura 6 Porcentagem de animais com presença de hemorragia na cóclea nos grupos Gc, Gr e Gegb+r

Figura 7 Fotomicrografia do corte histológico da cóclea do animal n.10 do grupo Gegb+r, onde pode ser visualizada hemorragia acentuada (corante:hematoxilina-eosina)

Figura 8 Fotomicrografia do corte histológico que mostra congestão na estria vascular do animal $\mathrm{n}^{0} \quad 20$ do grupo $\mathbf{G r}$ (corante:hematoxilina-eosina)

Figura 9 Eletromicrografia de varredura do corte histológico da citoarquitetura da cóclea do animal $\mathrm{n}^{0} 2$ do grupo Gc, demonstrando a preservação das três fileiras de células ciliadas externas

Figura 10 Eletromicrografia de varredura da integridade das células ciliadas externas e de seus estereocílios da citoarquitetura da cóclea no animal $n^{0} 1$ do grupo Gc

Figura 11 Eletromicrografia de varredura da citoarquitetura coclear com manutenção das três fileiras de células ciliadas externas na cobaia $n^{0} 8$ do grupo Gegb 
Figura 12 Eletromicrografia de varredura da integridade das células ciliadas externas da citoarquitetura do animal $n^{0} 7$ do grupo Gegb

Figura 13 Eletromicrografia de varredura da citoarquitetura da cóclea com presença de hemácias livres no interior de vaso sanguíneo coclear de animal $n^{0} 7$ do grupo Gegb

Figura 14 Eletromicrografia de varredura da manutenção da citoarquitetura da cóclea da cobaia $n^{0} 10$ do grupo $\mathbf{G e g b + r}$, com a presença das três fileiras de células ciliadas externas

Figura 15 Eletromicrografia de varredura da citoarquitetura coclear com edema e fusão ocasional de estereocílios na cobaia $\mathrm{n}^{0} 10$ do grupo Gegb+r

Figura 16 Eletromicrografia de varredura da citoarquitetura coclear com ausência de células ciliadas, vacuolização e edema celulares, e quebra dos esterocílios na cobaia $\mathrm{n}^{0} 20$ do grupo $\mathbf{G r}$

Figura 17 Eletromicrografia de varredura da citoarquitetura coclear com alongamento e fusão de estereocílios na cobaia $n^{0} 19$ do grupo Gr 73

Figura 18 Eletromicrografia de varredura da citoarquitetura da cóclea com alongamento, fusão e aspecto dos estereocílios da cobaia $n^{0} 19$ do grupo Gr. 


\section{LISTA DE TABELAS}

Tabela 1 Congestão capilar visualizada sob microscopia de luz na estria vascular, dos grupos Gc e Gegb

Tabela 2 Alterações do Órgão de Corti observadas sob microscopia de luz, nos grupos Gc e Gegb

Tabela 3 Alterações da membrana vestibular visualizadas em microscopia de luz, nos grupos Gc e Gegb

Tabela 4 Presença de hemorragia na cóclea, visualizada sob microscopia de luz, nos grupos Gc e Gegb

Tabela 5 Presença de congestão capilar, visualizada sob microscopia de luz, da estria vascular dos grupos Gc, Gr e Gegb

Tabela 6 Alterações do Órgão de Corti observadas com auxílio da microscopia de luz, nos grupos Gc, Gr e Gegb+r

Tabela 7 Alterações da membrana vestibular visualizadas em microscopia de luz, nos grupos Gc, Gr e Gegb+r

Tabela 8 Presença de hemorragia na cóclea visualizada sob microscopia de luz, nos grupos Gc, Gr e Gegb+r 


\section{RESUMO}

Silva NMAVM. Estudo da ação do nível elevado de pressão sonora e do extrato seco de Ginkgo biloba EGb 761 na citoarquitetura da cóclea de cobaias adultas [tese]. São Paulo: Faculdade de Medicina, Universidade de São Paulo; 2005. 96págs.

A preocupação com a exposição do Homem ao ruído excessivo data dos primórdios da civilização. Com a modernidade, os níveis de ruído têm sido crescentes não só nas atividades laborais, como também nas sociais e recreativas, levando à perda auditiva induzida por níveis de pressão sonora elevada (PAINPS) a ser considerada a segunda maior causa de surdez, e a enfermidade profissional mais freqüente nas comunidades urbanas industrializadas (Nudelmann et al, 1997). Esses fatos levaram a realizar trabalho experimental buscando uma droga de possível efeito otoprotetor. O objetivo foi estudar o efeito do nível de pressão sonora elevada e do extrato seco de Ginkgo biloba EGb 761 na cóclea de cobaias albinas, fêmeas e adultas, pela avaliação de eventuais alterações da sua citoarquitetura, por meio de microscopia de luz e pela observação das alterações do epitélio sensorial com microscopia eletrônica de varredura (MEV). Foram utilizadas 24 cobaias distribuídas em quatro grupos de estudo: Grupo controle (Gc) - 4 cobaias; Grupo extrato seco de Ginkgo biloba EGb 761 (Gegb) - 4 cobaias; Grupo extrato seco de Ginkgo biloba EGb 761 e exposto a ruído intenso $(\mathbf{G e g b}+\mathbf{r})$ - 8 cobaias; e, Grupo exposto a ruído intenso (Gr) - 8 cobaias. Foram incluídos animais que apresentaram otoemissões acústicas (OEA) no primeiro dia do experimento. Os animais dos grupos Gc e $\mathbf{G r}$ receberam soro fisiológico 0,9\% por via oral durante 30 dias. Os animais dos grupos Gegb e Gegb+r receberam extrato seco de Ginkgo biloba EGb 761 em solução por via oral durante 30 dias. No dia 31 os grupos $\mathbf{G r}$ e $\mathbf{G e g b}+\mathbf{r}$ foram submetidos a uma sessão de 30 minutos ininterruptos de ruído a $120 \mathrm{~dB}$ em câmara acústica semi-anecóica. No $34^{\circ}$ dia os animais de todos os grupos foram sacrificados e suas cócleas direitas, coloridas com hematoxilina-eosina (HE), foram analisadas sob microscopia de luz e as cócleas esquerdas por MEV. Observou-se congestão capilar na estria vascular significantemente maior nos grupos Gegb, Gegb+r e Gr quando comparados ao grupo Gc; não houve alteração no órgão de Corti e na membrana vestibular dos 
grupos Gc e Gegb, porém, os grupos Gegb+r e $\mathbf{G r}$ apresentaram alterações significantes quando comparados ao Gc; não se observou hemorragia no Gc, enquanto os grupos $\mathbf{G e g b}$, Gegb+r e $\mathbf{G r}$ apresentaram intensidades diferentes de hemorragia, estatisticamente significantes quando a ele comparados. A microscopia de luz mostrou que: 1) o efeito do ruído no epitélio sensitivo da cóclea: pelas alterações da membrana vestibular e órgão de Corti, significantemente mais freqüentes nos grupos $\mathbf{G r}$ e $\mathbf{G e g b}+\mathbf{r}$ em relação ao Gc e presença significante de hemorragia nos grupos $\mathbf{G r}$ e $\mathbf{G e g b}+\mathbf{r}$, quando comparada ao Gc; 2) o efeito do extrato seco de Ginkgo biloba EGb 761 na cóclea, pelo aumento significante da congestão vascular nas cobaias tratadas exclusivamente com a droga, Gegb, quando relacionado ao Gc e pela diferença significante observada no grau de congestão vascular nos diversos grupos: leve no Gc, discreta no $\mathbf{G r}$ e moderada no $\mathbf{G e g b}+\mathbf{r}$. Não foi possível demonstrar diferença significante na citoarquitetura da cóclea entre os animais expostos ao ruído e que receberam, ou não, o extrato seco de Ginkgo biloba EGb 761. As imagens da microscopia eletrônica de varredura sugerem que os dois grupos submetidos ao ruído, Gr e $\mathbf{G e g b + r}$, apresentaram lesões estruturais das células ciliadas e de sustentação, apesar das lesões observadas nos animais expostos ao ruído terem sido menos intensas no $\mathbf{G e g b + r}$, levantando-se a hipótese de um possível efeito protetor do extrato seco de Ginkgo biloba EGb 761.

Descritores: Efeitos do ruído - Poluição sonora - Perda auditiva provocada por ruído Ginkgo biloba/uso terapêutico - Cóclea/efeitos de drogas - Cobaias Microscopia eletrônica de varredura 


\section{SUMMARY}

Silva NMAVM. Study of the action of the high level of sound pressure and the dry extract of Ginkgo biloba EGb761 in the citoarchitecture of the cochlea of adult guinea-pigs [thesis]. São Paulo: "Faculdade de Medicina, Universidade de São Paulo"; 2005. 96pp.

Concern about Man's exposition to excessive noise dates from the origins of the civilization. In the Modern Era, noise levels have been growing not only at work, but also in social and leisure time activities, resulting in hearing loss induced by high intensity sound pressure levels as the second largest cause of deafness to be considered, being this professional illness more frequent in the industrialized urban communities (Nudelmann et al., 1997). These facts had resulted in the accomplishment of an experimental research looking for a drug with otoprotector effects. The aim of this work was to evaluate the effect of high pressure sound levels and the dry extract of Ginkgo biloba EGb 761 on the cochlea of albinic guinea-pigs, females and adult, for the evaluation of eventual alterations of the citoarchitecture by means of a light microscopy. In sensorial epithelium alterations studies a scanning electron microscopy (SEM) was used. Twenty-four albinic guinea pigs were divided into four groups: four animals in the control group (Gc); four in the Ginkgo biloba EGb761 dry extract group (Gegb); eight in the group Ginkgo biloba EGb761 dry extract exposed to high level noise $(\mathbf{G e g b}+\mathbf{n})$; and eight in the group exposed to high level noises (Gn). Animals that had had otoacoustic emissions (OAE) at the first day of the experiment have been included. To the ones in groups Gc and Gn 0.9\% saline solution was given orally for 30 days. The other ones, in groups $\mathbf{G e g b}$ and $\mathbf{G e g b + n}$, had a solution of Ginkgo biloba EGb 761 dry extract given orally for 30 days. On day 31 of the experiment the groups $\mathbf{G n}$ and $\mathbf{G e g b}+\mathbf{n}$ were submitted to 30 minutes non-stop session of noise at $120 \mathrm{~dB}$ inside an acoustic semi-anecoic chamber. At the $34^{\text {th }}$ day all the guinea pigs, of all groups, were euthanised/sacrificed. Their right cochleas has been stained with hematoxiline-eosine for examination under light microscopy and the left cochleas were evaluated by scanning electron microscopy (SEM). Capilar congestion was observed to be significantly higher in groups Gegb, $\mathbf{G e g b}+\mathbf{n}$ and $\mathbf{G n}$ when compared to the Gc group. Corti`s organ and the vestibular 
membrane did not present alterations in groups Gc e Gegb whereas in groups $\mathbf{G e g b + n}$ and $\mathbf{G n}$ were shown to have important alterations when compared to the $\mathbf{G} \mathbf{c}$ group. In group Gc no haemorrhage was seen while in groups Gegb, Gegb+n and Gn it was observed with different levels of intensity what was found to be statistically significant when compared to group Gc. Light microscopy was found to be able to demonstrate: 1) noise effect to the cochlear sensitive epithelium: by the alterations of the Corti's organ and vestibular membrane more frequently seen in groups $\mathbf{G n}$ e $\mathbf{G e g b + n}$ as compared to $\mathbf{G c}$ and the presence of haemorrhage in groups Gn e Gegb+n as compared to group Gc; 2) Ginkgo biloba EGb 761 dry extract effect to the cochlea by the significant increase on vascular congestion of the guinea pigs treated with that drug only (Gegb) compared to Gc and also by the difference observed of the level of vascular congestion in the groups: light in the Gc, discrete in the $\mathbf{G n}$ and moderate in the $\mathbf{G e g b}+\mathbf{n}$. It has been not possible to demonstrate significant differences to the cochlea cell architecture between the animals exposed to noise and to which Ginkgo biloba EGb 761 dry extract has been administered or not. Scanning electron microscopy images suggest that the animals of the groups $\mathbf{G n}$ and Gegb+n, exposed to noise, showed structural lesions of the ciliated and supportive cells even with lesions seen in animals exposed to noise being less intense in the Gegb+n group, raising the hypothesis of a possible protection effect of the Ginkgo biloba EGb 761.

Key-words: Noise effects - Sound pollution - Hearing loss caused by noise Ginkgo biloba/therapeutic use - Cochlea/drug effects - Guinea-pig - Scanning Electron Microscopy 
1.INTRODUÇÃO 


\section{INTRODUÇÃO}

A preocupação com a exposição do Homem ao ruído excessivo é muito antiga. Por volta do ano 720 antes da Era Cristã, tribos helênicas cruzaram o Mar Jônico fundando uma aldeia denominada Síbaris, que se tornou próspera, atraindo artesãos gregos, hábeis forjadores de bronze. Estes artesãos eram estrategicamente fixados fora do perímetro urbano da colônia para evitar que o barulho atingisse o resto da comunidade, sendo-lhes atribuídas as primeiras referências relacionadas com a prevenção do ruído ocupacional. De 50 a 44 a.C., Júlio César, imperador romano, proibiu que os veículos pesados movidos a tração animal rodassem sobre o pavimento de pedra da cidade durante a noite, para que não perturbassem o descanso dos cidadãos. Caius Plinius Secundus, conhecido como Plínio, o Velho, em sua obra clássica, Naturalis historia, faz menção em um de seus capítulos ao ensurdecimento das pessoas que viviam próximas às cataratas do Nilo, constituindo-se esta, talvez, na primeira referência escrita correlacionando surdez e exposição ao ruído. (Nudelmann et al, 1997)

Com a modernidade, os níveis de ruído têm sido crescentes não só nas atividades laborais, como também nas sociais e recreativas.

Os avanços tecnológicos que nos encaminham, aceleradamente, para um futuro muito próximo da ficção científica têm trazido consigo subprodutos perniciosos de 
poluição de controle difícil. Alguns, como os rejeitos radioativos, têm uma meia vida física de segundos a séculos. Outros, como o ruído, cessam imediatamente quando a atividade da fonte é suspensa, mas, nem por isso, são menos nocivos. Seus efeitos, em curto e médio prazo, podem causar desde um simples estado de neurotização passageira até lesões profundas e irreversíveis no aparelho auditivo com conseqüências marcantes para o ser humano. (Nudelmann et al, 1997)

Quando comparada a outras enfermidades, a surdez é a $3^{\mathrm{a}}$ causa mais freqüente de disfunção crônica no Homem, precedida apenas por hipertensão arterial e artrites (DeFeudis, 1998). De acordo com The National Institutes of Health, em 2003, quase um terço de todas as perdas auditivas pode ser atribuída à exposição ao ruído. A perda auditiva induzida por níveis de pressão sonora elevada (PAINPS) é considerada a segunda maior causa de surdez, e a enfermidade profissional mais freqüente nas comunidades urbanas industrializadas (Nudelmann et al, 1997). A PAINPS é, portanto, um problema de proporções epidêmicas. Estima-se que mais de 30 milhões de pessoas sejam expostas, diariamente, a um nível perigoso de ruído e que 10 milhões de norte americanos tenham danos acústicos irreversíveis com um custo entre 0,2 \% e 2 \% do Produto Interno Bruto nos países desenvolvidos (Seidman et al., 2003).

O National Institute for Occupational Safety and Health (NIOSH), em 2003, sugere haver perto de 30 milhões de americanos com exposição ocupacional a níveis intensos de ruído, acima de $85 \mathrm{~dB}(\mathrm{~A})$. Neste nível de exposição, um em quatro trabalhadores desenvolverá perda auditiva permanente. A prevalência e a 
irreversibilidade da PAINPS estimularam a busca de meios que pudessem evitá-la, porém, a base neuroquímica da cóclea era pouco conhecida até a década de 90, o que propiciou o desenvolvimento de estudos fisiológicos e farmacológicos para elucidação dos mecanismos fisiopatológicos que a envolvem (Puell, 1998).

Na literatura consultada, verifica-se a existência de material científico extenso e legal, com indicação de programas de proteção ao trabalhador e de conservação auditiva. Estes programas são embasados em ações físicas sobre as fontes geradoras de ruído, o ambiente, a conscientização do trabalhador, o uso de equipamento de proteção individual e a atuação na jornada de trabalho, porém, estudos que mostram que a cóclea pode ser protegida da PAINPS pelo uso de drogas otoprotetoras são extremamente raros.

A atividade industrial metalúrgica no município de Volta Redonda, RJ, a presença de inúmeras indústrias na região sul fluminense, assim como os índices elevados de exposição social a ruídos intensos tornam as queixas auditivas relacionadas ao excesso de ruído, muito freqüentes. Estes aspectos motivaram a busca de uma droga que possuísse efeitos protetores da cóclea contra os efeitos nocivos do ruído.

Com a certeza de que todas as ações preventivas devem ser realizadas em conjunto, foi proposto avaliar o efeito do extrato seco de Ginkgo biloba EGb 761 na citoarquitetura da cóclea exposta a nível elevado de pressão sonora como mais uma alternativa exeqüível e segura na proteção e conseqüente prevenção dos danos 
irreversíveis à cóclea. Ressalta-se, ainda, a possibilidade de criação de uma linha de pesquisa em otoproteção medicamentosa à cóclea exposta a níveis elevados de pressão sonora, visando a preencher a lacuna existente na literatura. 
2. OBJETIVO 


\section{OBJETIVO}

Estudar o efeito do nível de pressão sonora elevada e do extrato seco de Ginkgo biloba EGb 761 na cóclea de cobaias albinas, fêmeas e adultas com dois objetivos:

- Avaliar eventuais alterações da citoarquitetura da cóclea por meio de microscopia de luz;

- $\quad$ Observar as eventuais alterações do epitélio sensorial pela microscopia eletrônica de varredura. 
3. REVISÃO DA LITERATURA 


\section{REVISÃO DA LITERATURA}

\subsection{Ação do ruído na cóclea}

A exposição em níveis elevados de pressão sonora (acima de 90 dB) causa perda auditiva em conseqüência da lesão do órgão de Corti. A injúria à cóclea e/ou a perda auditiva dependem da intensidade e da duração de exposição ao ruído. Tal exposição pode resultar em perda auditiva temporária (TTS - temporary threshold shift), quando existe lesão moderada das sinapses e/ou dos estereocílios das células ciliadas, que pode ser reparada com posterior recuperação; ou evoluir para perda auditiva permanente (PTS - permanent threshold shift), quando existe lesão severa induzindo a apoptose e morte celular das células ciliadas e/ou dos neurônios com impossibilidade de recuperação. (Puel et al., 1998).

Puel et al., em 1998, descrevem que o ruído intenso induz à liberação excessiva de glutamato. Embora o glutamato seja o neurotransmissor excitatório ideal para a sinapse «célula ciliada interna-nervo acústico», quando em excesso é responsável por lesões no neurônio do gânglio espiral, por causa das suas propriedades excitotóxicas. A lesão excitotóxica resultante de estímulo sonoro intenso e do excesso de glutamato na fenda sináptica ocorre em duas fases: aguda e crônica ou tardia. Na fase aguda ocorre inicialmente um edema e posteriormente uma disjunção da terminação póssináptica. A sinapse entre a célula ciliada interna e o nervo auditivo é interrompido (perda auditiva súbita). Em virtude da plasticidade neuronal, a terminação dendrítica 
torna a crescer, reparando a sinapse, o que resulta na recuperação auditiva. No caso de trauma sonoro mais intenso ou de lesões repetidas (fase tardia), ocorre liberação excessiva de cálcio na fenda sináptica, alteração da homeostase dos canais de cálcio da terminação neuronal pós-sináptica e ativação dos receptores glutamatérgicos do tipo NMDA NR1, com conseqüente excitotoxicidade e apoptose celular (morte neuronal).

Oliveira, em 2001, afirma que a exposição ao ruído intenso pode determinar alterações mecânicas ou metabólicas na cóclea, principalmente nas estruturas vasculares e no órgão de Corti, onde as células ciliadas externas são as mais atingidas. Além das alterações no corpo celular, os estereocílios e seu sensível mecanismo de deslocamento são atingidos por ocasião do contato com a membrana tectorial durante a vibração da membrana basilar produzida pelo ruído. O ruído intenso provoca, principalmente nas células ciliadas externas, alterações citoplasmáticas e nucleares, edema da membrana com conseqüente comprometimento de permeabilidade, composição iônica e alterações vasculares na estria vascular. A geração de substâncias oxigênio-reativas é um mecanismo potencial de perda auditiva causada por superestimulação acústica. Essas substâncias, convertidas em radicais hidroxila, provocam peroxidação lipídica da membrana celular com conseqüente alteração da homeostase e do metabolismo energético e apoptose celular. O autor afirma ainda que os efeitos metabólicos e moleculares precedem as alterações estruturais, podendo ser revertidos. Neste estágio inicial, a audição pode ainda ser preservada, conquanto nos estágios em que o efeito mecânico já provocou lesões estruturais, estas são geralmente irreversíveis. 
De acordo com Lynch et al. (2004), mudanças bioquímicas como o aumento de radicais livres ou espécies de oxigênio e nitrogênio reativas, são ligadas à lesão coclear e morte de células ciliadas externas. Em particular, o peroxinitrito (ONOO$\left.{ }^{-}\right)$, um super-radical formado pela combinação do ânion superóxido e óxido nítrico, que causa peroxidação de lipídio, provocando sérias lesões das membranas das células ciliares. Uma mudança no nível da glutationa reduzida e/ou nível e atividade de enzimas que utilizam glutationa precipita a apoptose das células ciliadas externas. Os autores descrevem enzimas endógenas essenciais para a saúde e sobrevivência das células ciliadas externas e citam o papel da superóxido dismutase e glutationa peroxidase.

\subsection{Estudo estrutural da cóclea sob a ação do ruído}

\subsubsection{Microscopia de luz}

Os primeiros autores a estudarem a estrutura da cóclea sob a ação do ruído sob microscopia de luz foram Rüedi e Furrer (1946, apud Engström e Ades, 1960), que evidenciam que o ruído pode lesar as células da cóclea. Neubert (1952, apud Engström e Ades, 1960) demonstra alterações morfológicas no órgão de Corti com edema de núcleos celulares e Beck e Michler (1960, apud Engström e Ades, 1960) levam os estudos adiante, analisando as alterações estruturais no órgão de Corti com métodos histoquímicos. Vosteen (1958; 1960, apud Engström e Ades, 1960) também 
apresenta resultados usando métodos histoquímicos para análise do órgão de Corti exposto ao ruído intenso.

Fundamentados nos autores citados anteriormente, Engström e Ades, em 1960, descrevem as alterações estruturais no interior do órgão de Corti causadas por ruído intenso produzido por dois tipos diferentes de geradores de ruído, que emitem sons de avião, helicóptero, tiro e ruído branco. Vinte e cinco cobaias foram colocadas numa câmara de exposição especial e expostas por tempos variados a tons sinusoidais de diferentes freqüências e intensidade alta (acima de $135 \mathrm{~dB}$ ) e suas orelhas internas analisadas com microscopia eletrônica. Em sua série de experimentos, os autores, evidenciam alterações estruturais significativas no interior das células sensoriais, células de sustentação, terminações nervosas e células ganglionares. A primeira alteração encontrada foi na região infracuticular das células ciliadas, que apresentou acúmulo de material osmiofílico escuro (opaco) no interior de grânulos mitocondriais. O núcleo das células ciliadas apresentou edema, aumento de diâmetro e acúmulo irregular de massas de cromatina. O nucléolo mostrou-se bastante evidente e, freqüentemente, encontrado próximo à membrana nuclear. Após exposição prolongada, as mitocôndrias apresentaram edema e degeneração com mudanças nucleares pronunciadas. As células de Hensen tornaram-se esféricas e as células ganglionares apresentaram alterações nucleares, aumento dos nucléolos e acúmulo de grandes massas de cromatina. As células de sustentação apresentaram alterações semelhantes às descritas anteriormente. Após longa exposição, tanto as células de sustentação quanto as células ciliadas podiam estar totalmente 
degeneradas e desaparecer. A membrana basilar diversas vezes apresentou edema e, posteriormente, formação de escaras cicatriciais, causando aumento de impedância.

Beagley, em 1965, analisa as alterações histológicas do órgão de Corti de 20 cobaias expostas a ruído intenso (500 cps a $128 \mathrm{~dB}$, por 20 e 40 minutos), com microscopia de luz e microscopia eletrônica. O autor observou alterações máximas na terceira fileira de células ciliadas, na mesma proporção da alteração do limiar. Distorções no contorno das células ciliadas, semelhantes a uma rugosidade, foram vistas à microscopia eletrônica nos animais que apresentaram menor mudança de limiar. Nas maiores alterações de limiar, a distorção visualizada foi o edema, que culminou com ruptura das células ciliadas. Algumas vezes, o autor encontra aspecto estrelado das células ciliadas causado pelo grande edema das células de sustentação. Em menores alterações de limiar, o núcleo das células ciliadas apresentou-se com edema irregular e indentações na porção basal. Nas mudanças mais intensas do limiar, o edema do núcleo foi mais difuso. Grânulos osmiofílicos foram freqüentes, principalmente no ápice das células ciliadas externas. As mitocôndrias mantiveramse intactas. Corpúsculos de Hensen foram mais evidentes. Nas orelhas que apresentaram maior mudança de limiar, as preparações histológicas mostraram alterações em toda extensão da cóclea. As terminações e fibras nervosas mantiveramse intactas, sugerindo que essas estruturas sejam mais resistentes à estimulação sonora intensa quando comparadas às células ciliadas. A membrana basilar permaneceu intacta, assim como a lâmina reticular. Células de Deiters apresentaram edema apical. Ruptura das junções Hensen-Deiters foi observada sob microscopia óptica com fucsina, nos casos de discreta alteração de limiar. Após 14 dias, as 
mudanças das células ciliadas apresentaram diferentes graduações. Células ciliadas muito comprometidas foram vistas na porção basal da primeira espira em pequena quantidade. Na segunda espira, porém, esta proporção foi maior. Células de sustentação não apresentaram lesões significativas. A lâmina reticular manteve-se intacta, assim como as terminações e fibras nervosas. As células sensoriais pareciam praticamente normais.

\subsubsection{Microscopia eletrônica de varredura}

Bredberg et al., em 1970, realizam estudo comparativo, examinando epitélio sensorial da cóclea de cobaias e gatos controle, e expostos a ruído, por meio da microscopia eletrônica de varredura. Observam que nos animais normais a superfície do epitélio sensorial do órgão de Corti apresentou-se com os cílios das células sensoriais geometricamente arranjados em "W”. O primeiro sinal de lesão das células sensoriais expostas a trauma acústico foi o desarranjo dos estereocílios ou a degeneração completa dos mesmos, apesar de algumas células terem se mantido intactas. Na espira apical, foram documentadas alterações significativas, que incluíam fusão de vários estereocílios e a formação de cílios gigantes (mais longos e finos do que os normais). A placa cuticular das células apresentou-se deformada.

Hawkins Jr, em 1971, estuda as alterações encontradas no padrão celular do órgão de Corti, nos vasos sanguíneos abaixo das células internas e externas, nos vasos do ligamento espiral e na estria vascular, em 12 cobaias expostas ao ruído de 
banda larga (com nível de pressão sonora de 118 dB a 120 dB, por 8 a 110 horas). O autor encontrou grande parte dos vasos espirais com calibre normal nos animais expostos a oito horas de ruído, assim como padrão celular normal, embora tenha descrito constricção capilar significativa, bloqueando a passagem de células vermelhas. Alterações semelhantes foram descritas após 30 horas de ruído contínuo. Constricção mais intensa e difusa foi verificada após 110 horas de exposição intermitente durante período de 15 dias. Após oito horas de ruído houve perda ocasional de células ciliadas. Após 30 horas de ruído contínuo e 110 horas de ruído intermitente, houve perda mais significativa, principalmente das células ciliadas externas da terceira e de parte da segunda espira, com perda de estereocílios e vacuolização do citoplasma. As células ciliadas internas sofreram perdas isoladas ocasionais. Houve multiplicação de membranas parietais com formação de corpúsculos de Hensen. Em relação ao ligamento espiral, o autor evidenciou vasoconstricção e perda de capilares acima da membrana de Reissner. Descreveu vasos em processo de degeneração, deixando seus espaços pericapilares vazios como canais avasculares. Edema endotelial bloqueando a passagem de células vermelhas ocorreu acima e abaixo da estria. A constricção dos vasos da estria vascular foi infreqüente ou totalmente ausente após o ruído, apesar de ter havido evidência de sua atrofia após exposição prolongada.

Oliveira et al., em 1980, estudam cobaias expostas ao ruído branco de 115 dB, que tiveram seus limiares auditivos determinados pelo reflexo de Preyer e os estudos histológicos do órgão de Corti feitos pela técnica de preparação da superfície. Em exposições de 24 horas os limiares se alteraram, diminuindo a sensibilidade auditiva com recuperação incompleta entre 9-24 horas após o término da exposição. As lesões 
no órgão de Corti foram maiores nas células ciliadas externas da espira apical. Em exposições repetidas diárias de curta duração (1-2 horas) durante tempo prolongado (meses), os autores observaram que a recuperação após cada aplicação era dificultada até a instalação de alterações limiares permanentes, que correspondiam a lesões cocleares extensas.

\subsection{Emissões otoacústicas no ruído experimental}

Dagli e Canlon (1997) submetem cobaias, separadas em dois grupos diferentes, a ruído por dez dias consecutivos: expostas e não expostas previamente a estímulos sonoros. As emissões otoacústicas por produto de distorção foram utilizadas para monitoramento da perda auditiva induzida por exposição ao ruído. Como resultado, foi observado que o grupo exposto previamente a sons foi significativamente menos afetado pela superestimulação durante os dias iniciais de exposição a ruídos em comparação com o grupo não exposto. As cobaias acostumadas aos sons tornaram-se gradualmente mais afetadas pela superestimulação nas sessões diárias subseqüentes.

Khvoles et al. (1999) explicam que as emissões otoacústicas transitórias são muito usadas clinicamente. Tem sido difícil, entretanto, registrá-las em pequenos animais de laboratório. Após refinar a técnica, as emissões otoacústicas transitórias e emissões por produtos de distorção foram registradas em coelhos, ratos Psammonys obesus e cobaias. A intensidade dos estímulos de clique ficou entre $60 \mathrm{~dB}$ e $80 \mathrm{~dB}$ e, dependendo da espécie, deveria ser usada aproximadamente 5 - $10 \mathrm{~dB}$ acima do 
limiar. As respostas a um máximo de 2496 estímulos foram registradas no modo de aquisição não linear, a fim de reduzir artefatos cujos aparecimentos crescem linearmente com a intensidade do estímulo. Além disso, a técnica não linear elimina os efeitos da orelha média na resposta.

\subsection{Drogas otoprotetoras}

Hyppolito et al. (2003) descrevem que a Cisplatina é uma droga anti-neoplásica potente, largamente utilizada para o tratamento do câncer, tanto em adultos quanto em crianças. Entre seus efeitos colaterais, a ototoxicidade se apresenta como um dos mais importantes e leva à perda auditiva irreversível, bilateral, para as altas freqüências (4 kHz à $8 \mathrm{kHz}$ ). O objetivo dos autores foi avaliar, por meio das emissões otoacústicas por produtos de distorção (EOAPD) e por microscopia eletrônica de superfície (ME), a ação do extrato de Ginkgo biloba (EGb 761) na cóclea de cobaias albinas. Observaram EOAPD presentes pré e pós-tratamento no grupo EGb (100 mg/kg via oral) e 90 minutos após Cisplatina (80 mg/kg/dia via intraperitoneal) por oito dias. Verificaram que no grupo tratado com Ginkgo biloba a estrutura ciliar nas células ciliadas externas foi mantida em todas as espiras da cóclea, enquanto no grupo tratado somente com cisplatina as EOAPD desapareceram após o tratamento, com desaparecimento dos cílios das células ciliadas externas e distorção da arquitetura dos cílios remanescentes sob ME. Os autores concluem que a EGb, por sua ação anti-oxidante, atua como fator otoprotetor à ototoxicidade pela Cisplatina. 
Seidman et al. (2003) realizam estudo experimental com ratos Fischer para avaliar a capacidade de proteção do antioxidante resveratrol no sistema auditivo contra o dano por ruído. Os resultados demonstraram que os animais que receberam o resveratrol tiveram perda auditiva temporária reduzida em comparação ao grupo controle. Concluem que a terapia antioxidante é útil na prevenção da perda auditiva relacionada à isquemia e ao ruído.

Lynch et al. (2004) fizeram um estudo experimental em ratas submetidas à exposição única e repetida ao ruído, que receberam ebselen em veículo oral ou injetável, antes e depois do estímulo sonoro. Os animais foram avaliados com audiometria do tronco encefálico, microscopia óptica e de fluorescência. Como resultado, observaram que a resposta do tronco encefálico indicou que o ebselen proporcionou uma proteção significativa contra perda auditiva temporária e permanente após exposição a ruído único e repetido. Na média, três vezes mais células ciliares externas foram perdidas pelos controles em relação aos animais que receberam ebselen. Os autores concluem que o ebselen, assim como substâncias antiradicais livres e antioxidantes como alopurinol e superóxido dismutase, reduzem o nível da perda auditiva após exposição ao ruído.

\subsection{Mecanismo de ação do extrato de Ginkgo biloba_EGb 761}

Charagnac (1976) explica que a polivalência de ação do Ginkgo biloba é facilmente compreendida se for considerado que o EGb 761 age como um 
“trivasoregulador”, ou seja, influencia o sistema circulatório total e não apenas o sistema arterial, capilar ou venoso. Outras ações que não são especificamente ligadas ao sistema cardio-vascular, como a “neuroproteção”, também contribuem para a ação polivalente do EGb 761. A neuroproteção determina melhoria do metabolismo cerebral, proteção contra hipóxia e isquemia, efeitos protetores e curativos no edema cerebral, efeitos nos sistemas colinérgicos centrais, redução de “déficits” de neurotransmissores por causa da idade avançada, proteção contra danos às estruturas cerebrais e melhoria da adaptação ao estresse.

Dubreil (1986) confirma os bons resultados obtidos com Ginkgo biloba no sofrimento isquêmico das células sensoriais da cóclea. Essa hipótese é invocada diante de qualquer surdez coclear aguda, quer se trate de surdez súbita idiopática, quer se trate de surdez por traumatismo sonoro ou por barotraumatismo. Com efeito, além das propriedades hemodinâmicas, em particular sobre a microcirculação dos tecidos que sofreram isquemia, o Ginkgo biloba possui propriedades metabólicas que protegem as células com anóxia de suas conseqüências deletérias, em particular da peroxidação lipídica.

Clostre (1986) argumenta que o EGb 761 exerce ações vasculares, hemorreológicas e metabólicas, que permitem a ele "irrigar" preferencialmente tecido isquêmico.

Renon (1993) sugere que o benefício da Ginkgo biloba EGb 761 sobre a audição deve-se, em parte, à sua ação anti radicais livres. 
DeFeudis (1998) afirma que, embora compostos químicos puros tenham grande aplicabilidade, é essencial compreender que alguns dos benefícios terapêuticos obtidos com extratos de plantas dependem da combinação de seus constituintes. No caso do EGb 761, vários de seus constituintes são farmacologicamente ativos, o que responde pelos benefícios terapêuticos atingidos no tratamento de distúrbios químicos de origem multifatorial.

Hyppolito et al. (2003) argumentam que a Ginkgo biloba apresenta propriedades antioxidantes, atua diminuindo a peroxidação lipídica, aumentando os níveis de catalase, peróxido dismutase e glutadion. No plasma, também atua formando complexos com fosfolípides, aumentando sua atividade anti-oxidante. Em nível intracelular, atua em mitocôndrias, na fosforilação oxidativa do RNA mitocontrial e no Complexo de Golgi, auxiliando no mecanismo de reparo do DNA com melhora do "status antioxidante" celular e aumento dos níveis de glutadion intracelular e diminuição na incorporação de 3H-timidina. 
4. MÉTODOS 


\section{4_MÉTODOS}

Esta pesquisa foi idealizada no programa de Pós-Graduação da Disciplina de Otorrinolaringologia do Departamento de Oftalmologia e Otorrinolaringologia da Faculdade de Medicina da Universidade de São Paulo - FMUSP e realizada no laboratório de Cirurgia Experimental do Curso de Medicina do Centro Universitário Fundação Oswaldo Aranha - UNIFOA, em Volta Redonda, estado do Rio de Janeiro.

A pesquisa foi aprovada pelo Comitê de Ética em Pesquisa da UNIFOA (CoEP), protocolo n ${ }^{0}$ 05/2004 e pela Comissão de Ética para Análise de Projetos de Pesquisa (CAPPesq) do Hospital das Clínicas da Faculdade de Medicina da Universidade de São Paulo, protocolo n ${ }^{0}$ 339/04.

\subsection{Material}

\subsubsection{Amostra}

Com base em McCormick e Nuttall (1976), foram utilizadas 24 cobaias fêmeas, adultas, jovens, albinas, com massa média de 360 g, provenientes do biotério da Fundação Instituto Oswaldo Cruz - FIOCRUZ, RJ. Sob orientação do médico veterinário, especialista em animais silvestres, todos os animais foram mantidos no 
biotério em condições adequadas de ventilação e iluminação, com acesso livre à alimentação (ração para animais de laboratório, marca Purina - alimentação de roedores de laboratório e Hamsters) e hidratação.

Para admissão no estudo, os animais foram previamente submetidos à pesquisa de emissões otoacústicas transientes (OEA).

\subsubsection{Otoemissões Acústicas}

Para definir presença de função das células ciliadas externas em todos os animais, realizou-se a pesquisa das OEA transientes (Khvoles et al., 1999). Utilizouse aparelho de pesquisa das OEA, marca ILO 228 - ECHOPORT. Os animais foram sedados antes da realização da pesquisa das OEA com $20 \mathrm{mg} / \mathrm{kg}$ de massa de Thiopental Sódico (Laboratório Cristália) via intraperitoneal. Como critérios de normalidade observou-se, em 260 cliques: reprodutibilidade maior que 50\% nas freqüências individuais $(1,0 \mathrm{kHz} 50 \%=3 ; 1,5 \mathrm{kHz} 50 \%=3 ; 2,0 \mathrm{kHz} 50 \%=6$; $3,0 \mathrm{kHz} 50 \%=6 ; 4,0 \mathrm{kHz} 50 \%=6$ ) e estabilidade da sonda maior que $70 \%$.

\subsubsection{Critérios de inclusão}

- Presença de OEA. 
4.1.4 Critérios de exclusão

- Infecções na orelha média

- Rolha de cerúmen

\subsubsection{Formação dos Grupos}

Depois de verificados os critérios de inclusão e exclusão, os animais foram divididos aleatoriamente em quatro grupos, de acordo com os diferentes procedimentos a que foram submetidos:

- Grupo controle $(\mathbf{G c})$ : composto por quatro animais $\left(n^{0} 1\right.$ a 4$)$, tratados com soro fisiológico 0,9\%/via oral, sem exposição a ruído. Massa média dos animais $=387,5 \pm 96,9 \mathrm{~g}$

- Grupo controle do extrato seco de Ginkgo Biloba Egb 761 (Gegb): composto por quatro animais ( $\mathrm{n}^{0} 5$ a 8$)$ que utilizaram Ginkgo biloba EGb 761/via oral, sem exposição a ruído. Massa média dos animais $=338,5 \pm$ $33,7 \mathrm{~g}$

- Grupo extrato seco de Ginkgo biloba EGB 761 com ruído (Gegb+r): composto por oito animais ( $n^{0} 9$ a 16) submetidos a estímulo sonoro intenso após o uso de Ginkgo biloba EGb 761/via oral. Massa média dos animais = $356,1 \pm 23,3 \mathrm{~g}$ 
- Grupo ruído (Gr): composto por oito animais $\left(n^{0} 17\right.$ a 24$)$ que foram submetidos a estímulo sonoro intenso e receberam soro fisiológico 0,9\%/via oral. Massa média dos animais $=353,5 \pm 28,0 \mathrm{~g}$

Para cada grupo de animais, a quantidade de SF e EGb foi calculada em função da massa média dos animais. O volume em cada grupo foi de:

- Grupo Controle - Gc: Dose média de SF = 0,96 \pm 0,20 mL

- Grupo Extrato Seco de Ginkqo biloba Egb 761 - Gegb: Dose média de $\mathrm{EGb}=0,84 \pm 0,08 \mathrm{~mL}$

- Grupo Extrato Seco de Ginkgo biloba Egb 761 e Exposto ao Ruído -

$\underline{\mathbf{G e g b}+\mathbf{r}}$ : Dose média de EGb = 0,89 + 0,06 mL

- Grupo Exposto ao Ruído - Gr: Dose média de SF = 0,89 \pm 0,07 mL

\subsection{Método}

Após a inclusão no estudo, os animais foram submetidos aos procedimentos indicados para o grupo a que pertenciam. Todos os animais foram pesados diariamente em balança digital marca Gehaka BG 1000 II, para o cálculo da quantidade de droga e controle do experimento. 


\subsubsection{Droga de estudo}

A droga foi ministrada aos grupos Gegb e Gegb+r, diariamente durante 30 dias, a partir do primeiro dia do estudo (Dia 1), conforme os critérios a seguir:

- Extrato seco de Ginkgo biloba EGB761 (Tebonin ${ }^{\circledR}$, ALTANA Pharma, 40 mg/mL/20 gotas). (Jastreboff et al, 1997; Hyppolito et al., 2003);

- Dose administrada: $100 \mathrm{mg} / \mathrm{kg} /$ dia. (Jastreboff et al, 1997, Hyppolito et al., 2003);

- Via de administração: Oral, com seringa descartável de 5 mL;

- Tempo de administração: 30 dias.

Para mimetizar a tomada da droga, os grupos Gc e Gr receberam soro fisiológico 0,9\%, $100 \mathrm{mg} / \mathrm{kg} /$ dia, por via oral, com seringa descartável de $5 \mathrm{~mL}$, sendo submetidos à mesma manipulação e estresse que os grupos anteriores.

\subsubsection{Estímulo sonoro}

Os animais dos grupos Gr e Gegb+r foram submetidos a ruído intenso durante 30 min no $31^{\circ}$ dia do experimento.

Antes da estimulação sonora, os animais foram anestesiados conforme descrito anteriormente no item 4.1.2. 
O ruído apresentou as características seguintes:

- O ruído foi gerado por sirene piezoelétrica de alta potência GK - 10, único tom (GLK Eletrônica Ltda - Sirenes e Alarmes), com especificações de tensão mínima - $10 \mathrm{~V}$, nominal - $12 \mathrm{~V}$ e máxima - $15 \mathrm{~V}$; freqüência mínima - 2 kHz e máxima - 4 kHz; corrente mínima - 150 mA, nominal - 200 mA e máxima - 250 mA; potência mínima - 1,5 W, nominal - 2,4 W e máxima 3,75 W; potência sonora mínima - 120 dB, nominal - 121 dB e máxima $122 \mathrm{~dB}$; temperatura de operação mínima $-0{ }^{0} \mathrm{C}$, nominal $-25^{\circ} \mathrm{C}$ e máxima $-60{ }^{\circ} \mathrm{C}$.

- Duração da emissão do som de 30 min, em câmara acústica semi-anecóica com as dimensões seguintes: altura externa - $52 \mathrm{~cm}$; altura interna - $30 \mathrm{~cm}$; largura externa - 48 cm; largura interna - $30 \mathrm{~cm}$; comprimento externo - 60 cm e comprimento interno $-41 \mathrm{~cm}$.

- Os animais foram cuidadosamente posicionados com a cabeça exatamente abaixo da fonte sonora, com ambas as orelhas direcionadas para cima de modo a receberem simetricamente a pressão sonora. (Figura 1) 


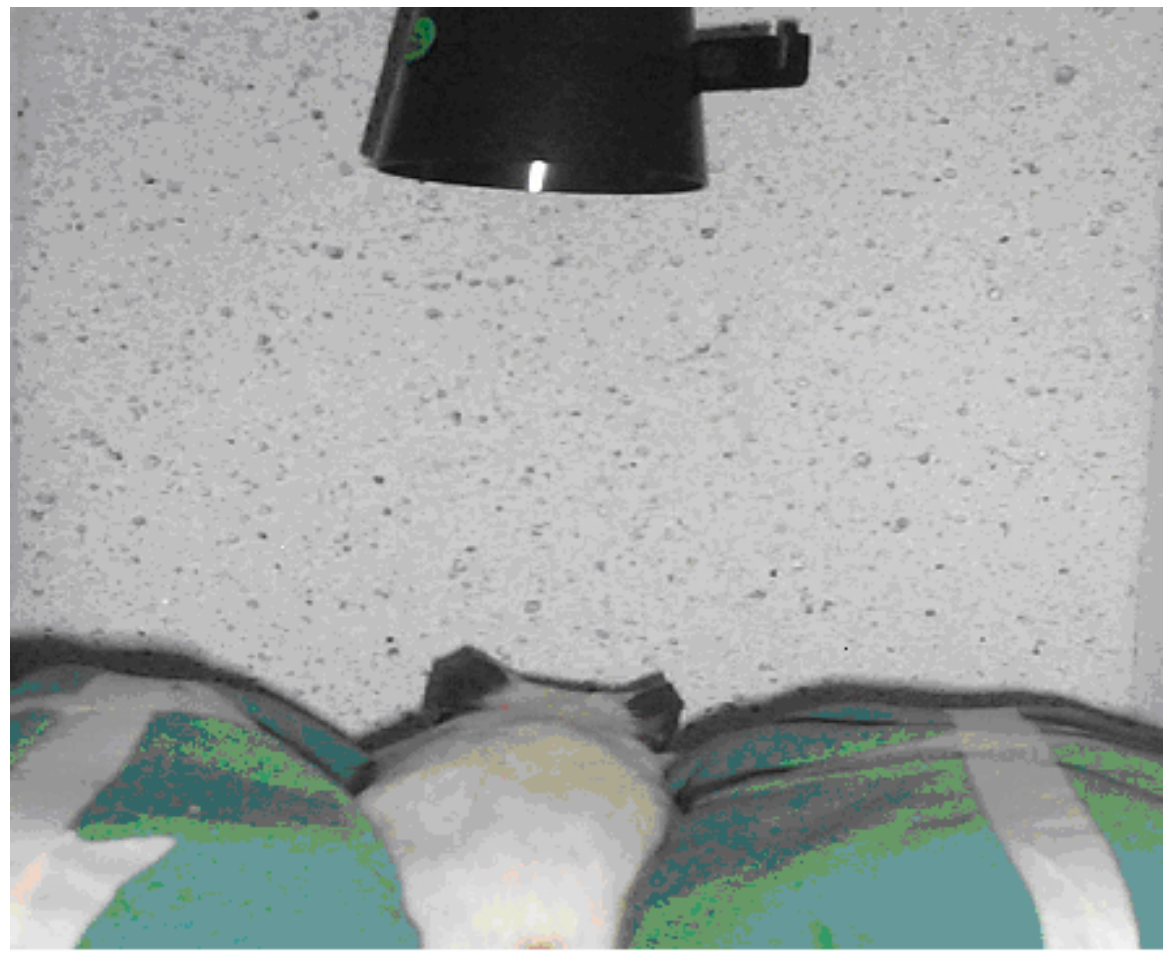

Figura 1 - Cobaia sedada no interior de câmara acústica semi-anecóica, posicionada com a cabeça exatamente abaixo da fonte sonora. $\mathrm{O}$ animal foi amparado por coxins para se manter inerte, com as orelhas paralelas em relação ao estímulo sonoro.

A potência sonora no interior da câmara acústica foi verificada pelo engenheiro de segurança do trabalho, com Calibrador Acústico Digital Instrutherm, modelo CAL - 1000, nº de série 00507149.

\subsubsection{Retirada dos Ossos Temporais}

No $34^{\circ}$ dia de estudo (Dia 34), todos os animais foram sedados com Thiopental Sódico 20 mg/kganimal via intra peritoneal e submetidos à dissecção cirúrgica de ambos os ossos temporais (direito e esquerdo) com remoção das respectivas cócleas, 
e sacrificados, ainda sedados, com dose letal de Thiopental Sódico (2mL via intraperitoneal).

A remoção cirúrgica seguiu as etapas seguintes:

- Tricotomia da região dorsal do crânio até a região cervical;

- Incisão dorsal no crânio, em “T” invertido, até a exposição de periósteo;

- Descolamento de periósteo, com rebatimento de retalhos, incluindo os pavilhões auriculares;

- Visualização de membranas timpânicas ao microscópio cirúrgico marca DF Vasconcelos, com oculares 200 mm;

- Infiltração, sob microscopia, de solução de formol tamponado através de janela redonda nas orelhas direitas;

- Infiltração de Thiopental Sódico 2 mL intraperitoneal com o objetivo letal;

- Incisão longitudinal na sutura sagital do crânio, com remoção de cúpula óssea craniana, expondo superior e medialmente ambas as cócleas;

- Secção de arco zigomático, com exposição antero-lateral das cócleas;

- Liberação das cápsulas óticas com microdissecção das cócleas.

Após remoção cirúrgica, os ossos temporais foram preparados para o estudo de sua citoarquitetura. As cócleas esquerdas seguiram para avaliação ultraestrutural por Microscopia Eletrônica de Varredura (MEV) e as cócleas direitas foram submetidas ao estudo histológico por Microscopia de Luz, seguindo as rotinas abaixo. 


\subsubsection{Avaliação da Citoarquitetura da Cóclea}

\subsubsection{Microscopia Eletrônica de Varredura}

A citoarquitetura coclear, avaliada com auxílio da microscopia eletrônica de varredura, microscópio marca Carl Zeiss - DSM940 (Oberkochen, Germany), seguiu as recomendações de Silveira (1998):

- Seleção e limpeza das cócleas esquerdas;

- Pré-fixação em Tampão Cacodilato 0,1 M + Sacarose 3,5\% + Glutaraldeído 2,5\% + Paraformaldeído 1\%, por 24 horas, em temperatura de $4{ }^{\circ} \mathrm{C}$;

- Lavagem em Tampão Cacodilato 0,1 M + Sacarose 3,5\%;

- Pós-fixação em $\mathrm{OsO}_{4}$;

- Lavagens;

- Impregnação metálica;

- Desidratação em etanol;

- Fluido de transição;

- Secagem no aparelho de Ponto Crítico;

- Montagem sobre os discos;

- Camada Condutora (Sputtering), com ouro;

- Observação no MEV. 


\subsubsection{Microscopia de Luz}

- Seleção e limpeza das cócleas direitas previamente perfundidas com solução de formol tamponado através das janelas redondas;

- Manutenção das cócleas direitas na solução de formol tamponado (formol 10\% acrescido de 4,0 g de fosfato de sódio monobásico e 6,5 g de fosfato de sódio dibásico, para cada litro) por no mínimo 24 h;

- Descalcificação, por aproximadamente 48 h, em solução composta de ácido etilenodiamino tetra acético - EDTA (ethylenediamine tetraacetic acid), ácido clorídrico e tartarato de sódio e potássio;

- Desidratação em álcool absoluto, seguida por clareamento em xilol;

- Banhos em parafina à $56{ }^{\circ} \mathrm{C}$ e inclusão em blocos de parafina;

- Cortes de $5 \mu \mathrm{m}$ a $6 \mu \mathrm{m}$ em micrótomo rotativo convencional, que foram recolhidos em água e estendidos em lâminas de vidro;

- Secagem em estufa a $56{ }^{\circ} \mathrm{C}$ por $30 \mathrm{~min}$;

- Coloração com Hematoxilina de Harris e Eosina para análise em microscópio de luz Carl Zeiss light microscope (Oberkochen, Germany).

Para avaliação histológica do tecido foram atribuídos valores numéricos às diversas alterações observadas nas estruturas analisadas, segundo sua intensidade ao microscópio. Foram avaliadas as alterações seguintes:

- Congestão capilar na estria vascular: 0 - congestão discreta; 2 - congestão moderada, capilares dilatados contendo hemácias; 3 - congestão acentuada, 
presença de massas homogêneas nos capilares, áreas de ruptura e extravasamento de hemácias;

- Órgão de Corti: 1 - alterações discretas nas células ciliadas com abertura de espaços; 2 - degeneração de grande número de células e membrana tectória com presença de alguns restos celulares no líquido; 3 - destruição total;

- Membrana vestibular: 0 - sem alterações; 1 - discreto apagamento nuclear; 2 - células pouco definidas com discreta granulação; 3 - rompimento com destruição das células;

- Hemorragia: 0 - ausência; 1 - discreta, apenas nas membranas; 2 moderada; 3 - acentuada, nas membranas e nas cavidades.

As etapas descritas podem ser observadas no cronograma que segue (Figura 2):

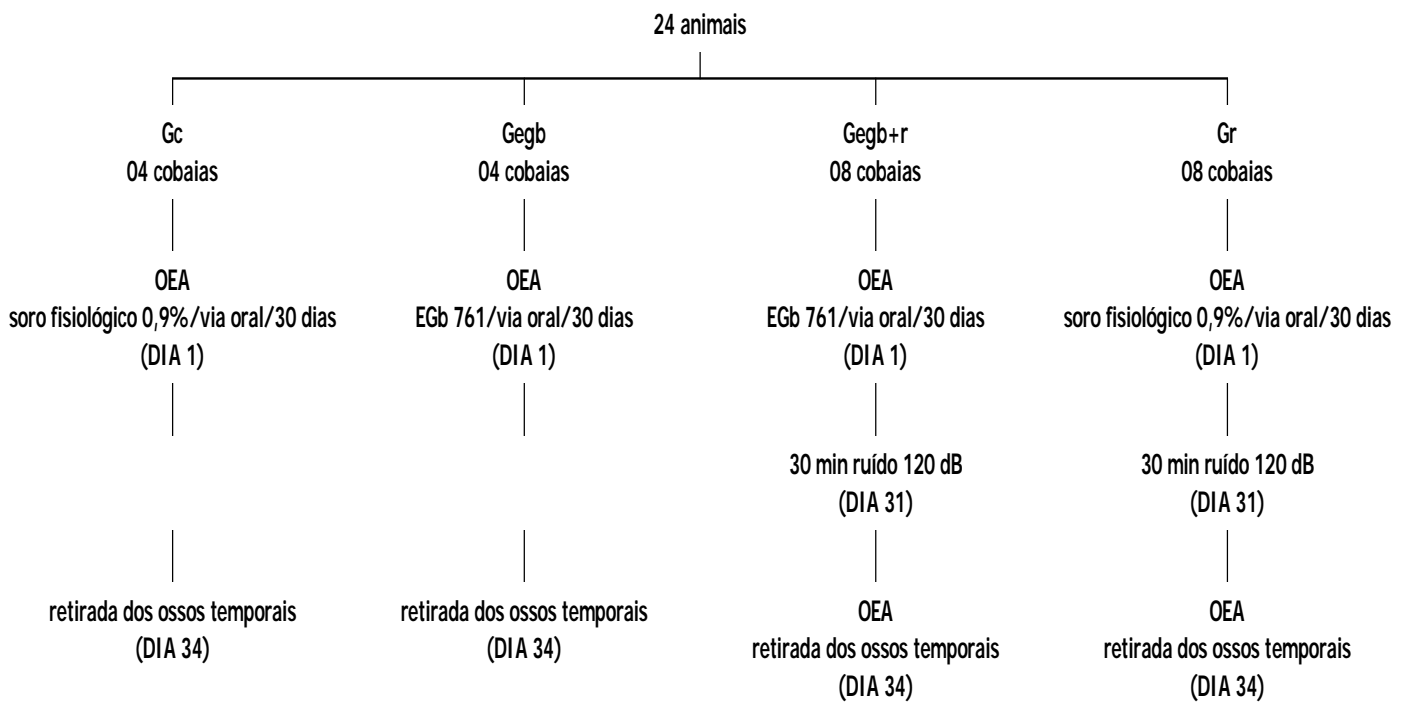

Figura 2 - Cronograma que mostra os procedimentos adotados, durante a pesquisa realizada, para cada grupo de animais. 


\subsubsection{Registro fotográfico de imagens}

Para registrar as reações das cobaias foi usada uma máquina fotográfica digital, marca Sony Cyber Shot modelo DSC-P10, com temporizador.

\subsection{Análise Estatística}

\subsubsection{Cálculo da amostra}

O tamanho da amostra foi calculado esperando-se observar diferença significativa na citoarquitetura coclear do grupo avaliado com uso de Extrato Seco de Ginkgo biloba EGB761 antes da emissão do ruído. A extensão da lesão coclear foi avaliada por meio da integridade das células ciliadas externas do órgão de Corti com microscopia eletrônica de varredura e ainda pela congestão capilar na estria vascular, alterações no órgão de Corti, membrana vestibular e vasos sangüíneos observadas à microscopia de luz.

\subsubsection{Metodologia estatística}

As variáveis quantitativas foram descritas por meio de sua média mais ou menos o desvio padrão e as categóricas por sua distribuição de freqüências. 
$\mathrm{Na}$ avaliação dos resultados encontrados os testes estatísticos empregados foram: a razão de verossimilhança e o Qui-quadrado com análise dos resíduos padronizados. Foram considerados significantes valores de $\mathrm{p}<0,05$ em testes bicaudais.

Os resultados foram apresentados sob forma de tabelas. 
5. RESULTADOS 


\section{RESULTADOS}

\subsection{Otoemissões Acústicas}

As OEA estavam presentes em todos os animais. Por ocasião da segunda avaliação, os dois grupos não expostos ao ruído (Gc e Gegb) mantiveram-nas. Os grupos expostos ao ruído (Gr e Gegb+r) não apresentaram resposta ao exame.

Não se observou diferença, quanto à presença de otoemissões acústicas após a exposição ao ruído, entre os animais que receberam e que não receberam EGb 761.

\subsection{Avaliação da citoarquitetura da cóclea}

\subsubsection{Microscopia de Luz}

\subsubsection{Ação do extrato seco de Ginkgo biloba EGb 761 (Gc X Gegb)}

A Tabela 1 mostra a existência de congestão capilar na estria vascular dos animais dos grupos Gc e Gegb, visualizada sob microscópio de luz. 
Tabela 1 - Congestão capilar visualizada sob microscópio de luz na estria vascular, dos grupos Gc e Gegb

\begin{tabular}{cc|c|c|c|c}
\hline \hline \multirow{2}{*}{ Grupo de estudo } & \multicolumn{4}{|c}{ Congestão capilar } \\
\cline { 3 - 6 } & Discreta & Moderada & Acentuada & Total \\
\hline \multirow{2}{*}{ Gc N (\%) } & $4(100 \%)$ & - & - & $4(100 \%)$ \\
Gegb & $\mathbf{N}(\%)$ & - & - & $4(100 \%)$ & $4(100 \%)$ \\
\hline \hline
\end{tabular}

Razão de verossimilhança: $\mathrm{p}=0,001$

Observou-se congestão significantemente mais intensa no grupo de animais Gegb comparada com a observada no grupo Gc.

Não foram encontradas alterações que pudessem ser enquadradas na classificação 1 (moderada), portanto, esta categoria foi retirada para fins gráficos.

A Tabela 2 mostra os resultados das alterações do Órgão de Corti dos animais dos grupos Gc e Gegb, observadas sob microscopia de luz.

Tabela 2 - Alterações do Órgão de Corti observadas sob microscopia de luz nos grupos Gc e Gegb

\begin{tabular}{|c|c|c|c|c|c|}
\hline \multirow{2}{*}{\multicolumn{2}{|c|}{ Grupo de estudo }} & \multicolumn{4}{|c|}{ Alterações do Órgão de Corti } \\
\hline & & $\begin{array}{l}\text { Alterações } \\
\text { discretas }\end{array}$ & Degeneração & Destruição & Total \\
\hline Gc & N (\%) & $2(50 \%)$ & $2(50 \%)$ & - & $4(100 \%)$ \\
\hline Gegb & N (\%) & $2(50 \%)$ & $2(50 \%)$ & - & $4(100 \%)$ \\
\hline
\end{tabular}


Não foi constatada associação entre a utilização de EGb 761 e as alterações observadas no Órgão de Corti. Não foram observadas alterações de classe zero, portanto, esta categoria foi retirada para fins de cálculo estatístico.

A Tabela 3 mostra as alterações da Membrana Vestibular visualizadas em microscopia de luz, nos grupos Gc e Gegb.

Tabela 3 - Alterações da membrana vestibular, visualizadas em microscopia de luz, nos grupos Gc e Gegb

\begin{tabular}{|c|c|c|c|c|c|c|}
\hline \multirow{2}{*}{\multicolumn{2}{|c|}{$\begin{array}{l}\text { Grupo de } \\
\text { estudo }\end{array}$}} & \multicolumn{5}{|c|}{ Alterações da membrana vestibular } \\
\hline & & Ausentes & $\begin{array}{c}\text { Apagamento } \\
\text { nuclear } \\
\text { discreto }\end{array}$ & $\begin{array}{c}\text { Células } \\
\text { pouco } \\
\text { definidas }\end{array}$ & $\begin{array}{c}\text { Destruição } \\
\text { celular }\end{array}$ & Total \\
\hline Gc & $\mathbf{N}(\%)$ & $3(75 \%)$ & $1(25 \%)$ & - & - & $4(100 \%)$ \\
\hline Gegb & $\mathbf{N}(\%)$ & $2(50 \%)$ & $2(50 \%)$ & - & - & $4(100 \%)$ \\
\hline
\end{tabular}

Razão de verossimilhança: $\mathrm{p}=0,462$

Após a análise dos resultados obtidos, não foi observada associação entre a utilização de Egb 761 e as alterações constatadas na membrana vestibular.

A Tabela 4 exibe dados sobre a presença de hemorragia na cóclea, visualizada sob microscopia de luz, nos grupos Gc e Gegb. 
Tabela 4 - Presença de hemorragia na cóclea, visualizada sob microscopia de luz, nos grupos Gc e Gegb

\begin{tabular}{c|c|c|c|c|c}
\hline \hline \multirow{2}{*}{ Grupo de estudo } & \multicolumn{5}{c}{ Hemorragia na cóclea } \\
\cline { 2 - 6 } & Ausente & Discreta & Moderada & Acentuada & Total \\
\hline \multirow{2}{*}{ Gc N (\%) } & $4(100 \%)$ & - & - & $4(100 \%)$ \\
Gegb N (\%) & $1(25 \%)$ & $3(75 \%)$ & - & $4(100 \%)$ \\
\hline \hline
\end{tabular}

Razão de verossimilhança: $\mathrm{p}=0,014$

Não se observou hemorragia no Gc e no Gegb, em três casos, nestes a hemorragia foi discreta. Esta diferença é estatisticamente significante.

5.2.1.2 Ação do extrato seco de Ginkgo biloba EGb 761 e Otoproteção ao estímulo sonoro intenso (Gc X GrX Gegb+r)

A Tabela 5 mostra os resultados das análises em microscopia de luz da presença de congestão capilar na estria vascular nos animais dos grupos Gc, Gr e Gegb 
Tabela 5 - Presença de congestão capilar, visualizada sob microscopia de luz, na estria vascular dos grupos Gc, Gr e Gegb

\begin{tabular}{|c|c|c|c|c|c|}
\hline \multirow{2}{*}{\multicolumn{2}{|c|}{ Grupo de estudo }} & \multicolumn{4}{|c|}{ Congestão capilar } \\
\hline & & Discreta & Moderada & Acentuada & Total \\
\hline Gc & N (\%) & $4(100 \%)$ & - & - & $4(100 \%)$ \\
\hline Gr & N (\%) & - & $2(28,6 \%)$ & $5(71,4 \%)$ & $7(100 \%)$ \\
\hline Gegb $+\mathbf{r}$ & N (\%) & - & 7 (87,5\%) & $1(12,5 \%)$ & 8 (100\%) \\
\hline
\end{tabular}

Qui-quadrado: $\mathrm{p}<0,0001$

A diferença, quanto à congestão capilar na estria vascular, observada nos três grupos é estatisticamente significante, destacando-se congestão discreta vista no grupo Gc, congestão acentuada em $\mathbf{G r}$ e congestão moderada em $\mathbf{G e g b}+\mathbf{r}$. Um animal do grupo Gr não foi submetido à quantificação histológica da congestão por dificuldades técnicas, e neste caso a amostra ficou reduzida a 7 animais $(\mathrm{N}=7)$.

A Figura 3 mostra a porcentagem de animais com congestão capilar na estria vascular em intensidade discreta, moderada e acentuada, nos grupos Gc, Gr e Gegb+r. 


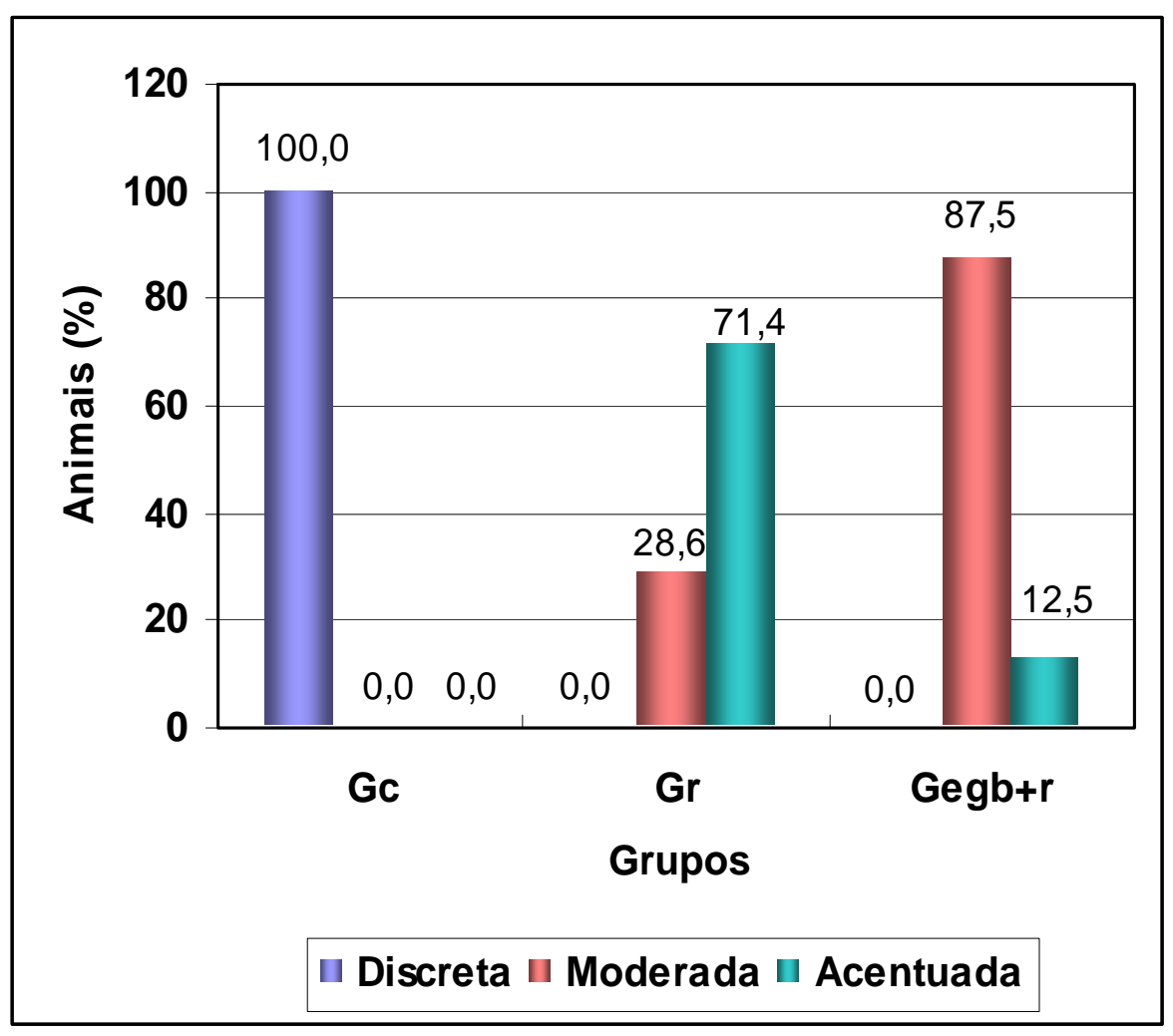

Figura 3 - Porcentagem de animais com congestão capilar na estria vascular em intensidade discreta, moderada e acentuada, nos grupos Gc, Gr e Gegb+r

Na Tabela 6 podem ser vistos os resultados da avaliação das alterações do Órgão de Corti nos animais dos grupos Gc, Gr e Gegb+r, sob microscopia de luz. 
Tabela 6 - Alterações do Órgão de Corti, observadas com auxílio da microscopia de luz, nos grupos Gc, Gr e Gegb+r

\begin{tabular}{lc|c|c|c|c}
\hline \multirow{2}{*}{ Grupo de estudo } & \multicolumn{5}{|c}{ Alterações do Órgão de Corti } \\
\cline { 3 - 6 } & $\begin{array}{c}\text { Alterações } \\
\text { discretas }\end{array}$ & Degeneração & Destruição & Total \\
\hline Gc & $\mathbf{N}(\%)$ & $2(50 \%)$ & $2(50 \%)$ & - & $4(100 \%)$ \\
Gr & $\mathbf{N}(\%)$ & - & - & $8(100 \%)$ & $8(100 \%)$ \\
Gegb+r & $\mathbf{N}(\%)$ & - & - & $8(100 \%)$ & $8(100 \%)$ \\
\hline \hline
\end{tabular}

Qui-quadrado: $\mathrm{p}<0,0001$

A diferença observada na distribuição das alterações do órgão de Corti é estatisticamente significante. Esta diferença foi causada pela maior intensidade das alterações observadas nos grupos $\mathbf{G r}$ e $\mathbf{G e g b + r}$, quando comparados com o grupo Gc.

A Figura 4 mostra a porcentagem de animais com alterações no órgão de Corti, discretas, degenerativas e destrutivas, nos grupos Gc, Gr e Gegb+r. 


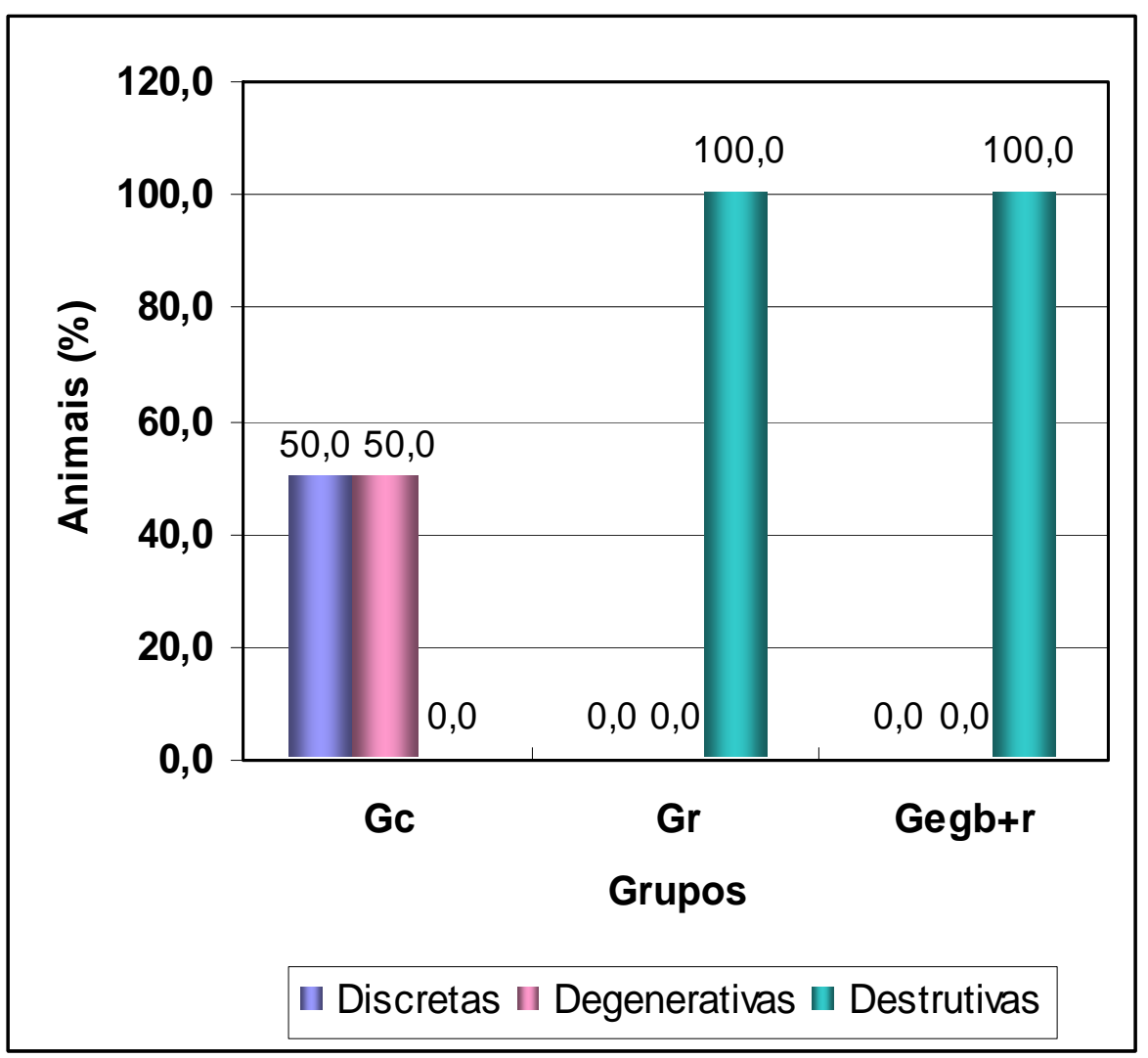

Figura 4 - Porcentagem de animais com alterações no órgão de Corti, discretas, degenerativas e destrutivas, nos grupos Gc, Gr e Gegb+r.

Na Tabela 7 podem ser vista a porcentagem de animais que mostraram alterações na membrana vestibular visualizada em microscopia de luz, nos grupos Gc, Gr e Gegb+r. 
Tabela 7 - Alterações na membrana vestibular, visualizadas em microscopia de luz, nos grupos Gc, Gr e Gegb+r

\begin{tabular}{lc|c|c|c|c|c}
\hline \multirow{2}{*}{ Grupo de estudo } & \multicolumn{5}{|c}{ Alterações da membrana vestibular } \\
\cline { 2 - 6 } & Ausentes & $\begin{array}{c}\text { Apagamento } \\
\text { nuclear } \\
\text { discreto }\end{array}$ & $\begin{array}{c}\text { Células } \\
\text { pouco } \\
\text { definidas }\end{array}$ & $\begin{array}{c}\text { Destruição } \\
\text { celular }\end{array}$ & Total \\
\hline Gc & $\mathbf{N ~ ( \% )}$ & $3(75 \%)$ & $1(25 \%)$ & - & - & $4(100 \%)$ \\
Gr & $\mathbf{N}(\%)$ & - & - & $1(12,5 \%)$ & $7(87,5 \%)$ & $8(100 \%)$ \\
Gegb+r & $\mathbf{N ~ ( \% ) ~}$ & - & - & $1(12,5 \%)$ & $7(87,5 \%)$ & $8(100 \%)$ \\
\hline \hline
\end{tabular}

Qui-quadrado: $\mathrm{p}=0,003$

A diferença observada na distribuição das alterações da membrana vestibular é estatisticamente significante. Esta diferença foi causada pela intensidade maior das alterações observadas em Gr e Gegb+r, quando comparados ao Gc.

A Figura 5 mostra quantos animais apresentaram alterações na membrana vestibular, nos grupos Gc, Gr e Gegb+r. 


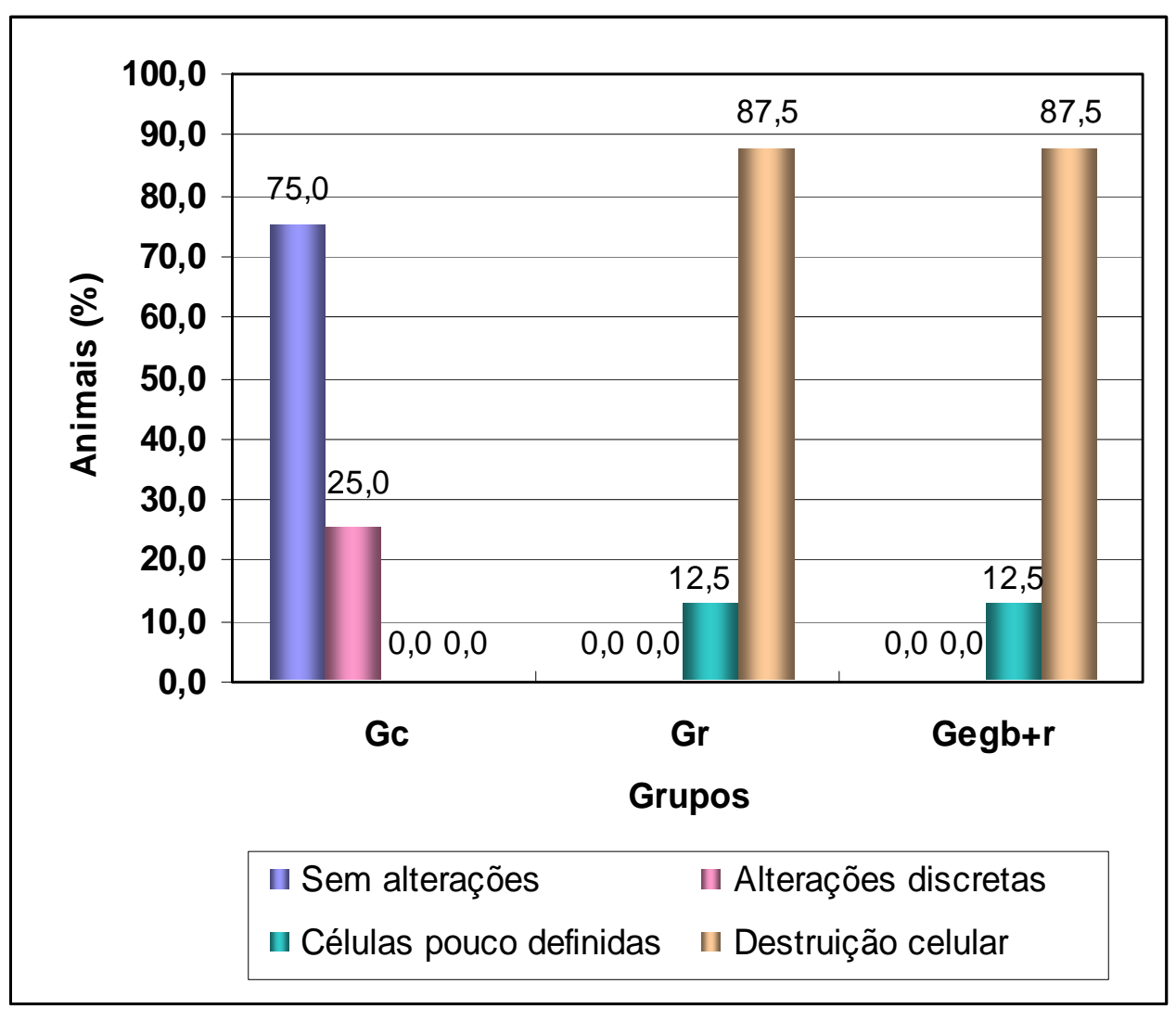

Figura 5 - Porcentagem de animais que apresentou alterações na membrana vestibular, nos grupos Gc, Gr e Gegb+r.

A Tabela 8 mostra a presença de hemorragia na cóclea, visualizada sob microscopia de luz, nos grupos Gc, Gr e Gegb+r. 
Tabela 8 - Presença de hemorragia na cóclea visualizada sob microscopia de luz, nos grupos Gc, Gr e Gegb+r

\begin{tabular}{lc|c|c|c|c|c}
\hline \multirow{2}{*}{} & \multicolumn{5}{|c}{ Hemorragia na cóclea } \\
\cline { 3 - 7 } Grupo de estudo & Ausente & Discreta & Moderada & Acentuada & Total \\
\hline Gc & $\mathbf{N}(\%)$ & $4(100 \%)$ & - & - & - & $4(100 \%)$ \\
Gr & $\mathbf{N}(\%)$ & - & $2(25,0 \%)$ & $3(37,5 \%)$ & $3(37,5 \%)$ & $8(100 \%)$ \\
Gegb+r & $\mathbf{N}(\%)$ & - & $1(12,5 \%)$ & $2(25,0 \%)$ & $5(62,5 \%)$ & $8(100 \%)$ \\
\hline \hline
\end{tabular}

Qui-quadrado: $\mathrm{p}=0,002$

A diferença observada na distribuição da intensidade da hemorragia foi significante. Esta diferença foi causada pela ausência de hemorragia observada no Gc e os grupos $\mathbf{G r}$ e Gegb+r mostraram comportamento semelhante.

A Figura 6 mostra a porcentagem de animais com presença de hemorragia na cóclea nos grupos Gc, Gr e Gegb+r. 


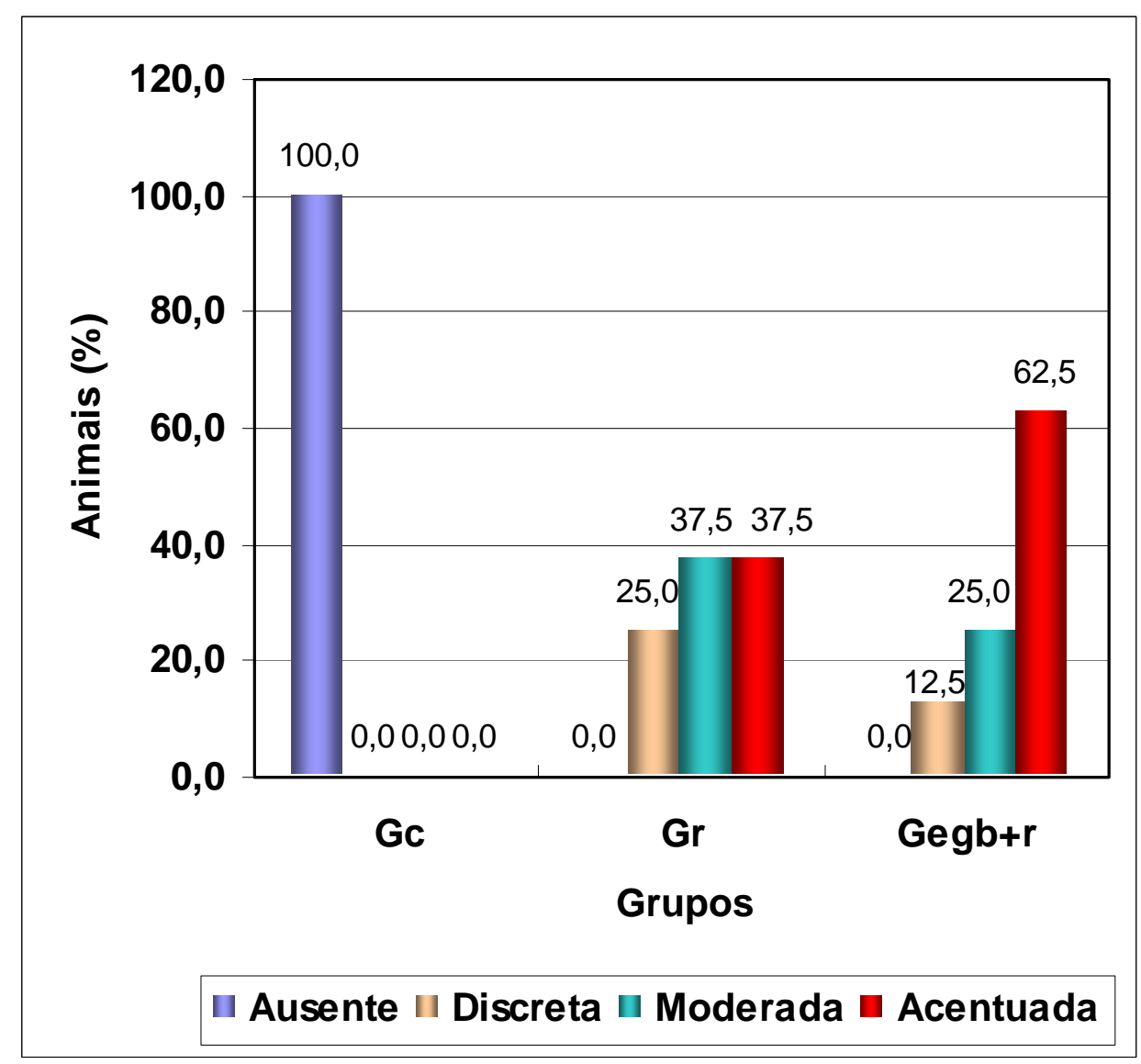

Figura 8 - Porcentagem de animais com presença de hemorragia na cóclea nos grupos Gc, Gr e Gegb+r.

A Figura 7 mostra a fotomicrografia do corte histológico da cóclea do animal $n^{\circ} 10$ do grupo Gegb+r, corado com HE, visto sob microscópio de luz, no qual pode ser visualizada hemorragia acentuada. 


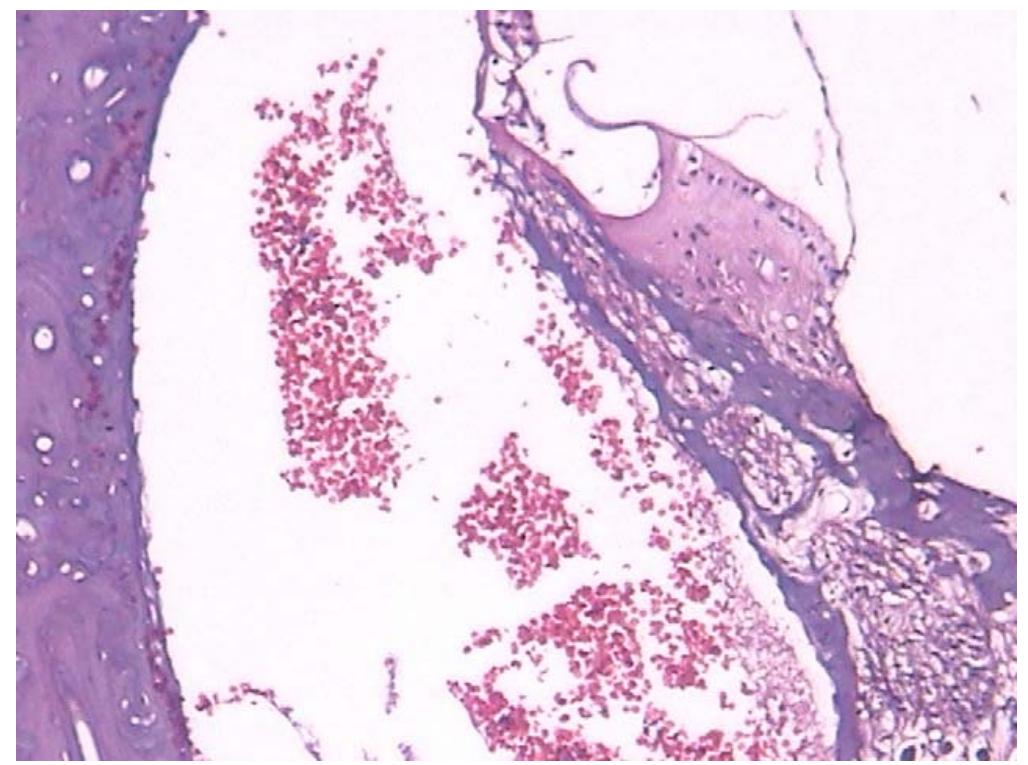

Figura 7 - Fotomicrografia do corte histológico da cóclea do animal $\mathrm{n}^{0} 10$ do grupo $\mathbf{G e g b}+\mathbf{r}$, onde pode ser visualizada hemorragia acentuada. (corante hematoxilina-eosina)

A Figura 8 mostra a fotomicrografia do corte histológico no qual pode ser vista congestão na estria vascular do animal $n^{0} 20$ do grupo Gr.

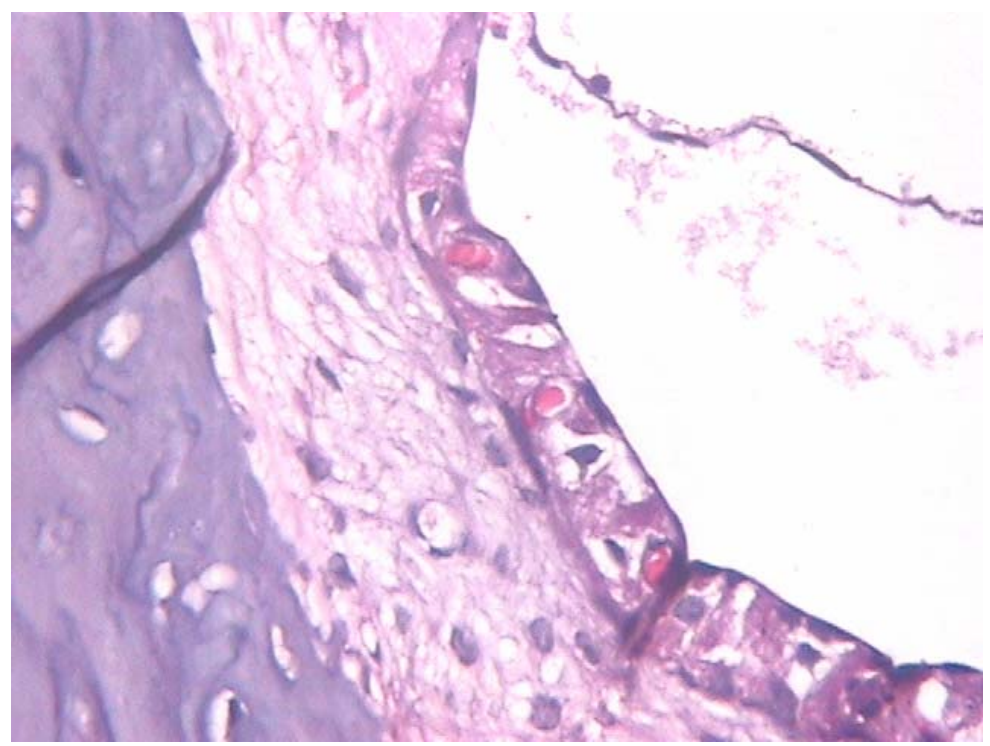

Figura 8 - Fotomicrografia do corte histológico que mostra congestão na estria vascular do animal $n^{\circ} 20$ do grupo Gr. (corante - hematoxilinaeosina) 


\subsubsection{Microscopia Eletrônica de Varredura (MEV)}

\subsubsection{Grupo Controle - Gc}

A Figura 9 mostra a eletromicrografia de varredura da citoarquitetura da cóclea do animal $n^{0} 2$ do grupo Gc, com a preservação das fileiras de células ciliadas externas, da integridade dos corpos celulares e dos estereocílios.

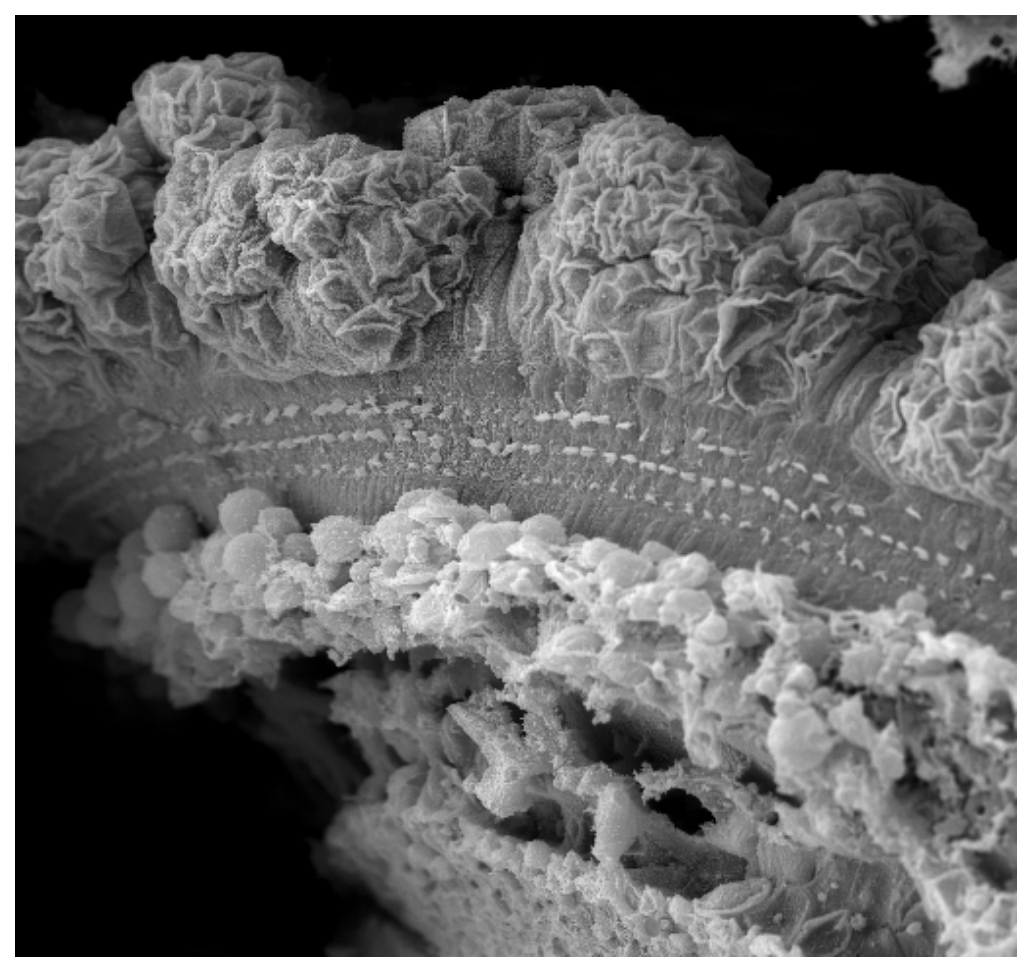

Figura 9 - Eletromicrografia de varredura do corte histológico da citoarquitetura da cóclea do animal $n^{0} 2$ do grupo Gc, demonstrando a preservação das três fileiras de células ciliadas externas.

A Figura 10 mostra a eletromicrografia de varredura da integridade das células ciliadas externas e de seus estereocílios da citoarquitetura da cóclea no animal $n^{\circ} 1$ do grupo Gc. 


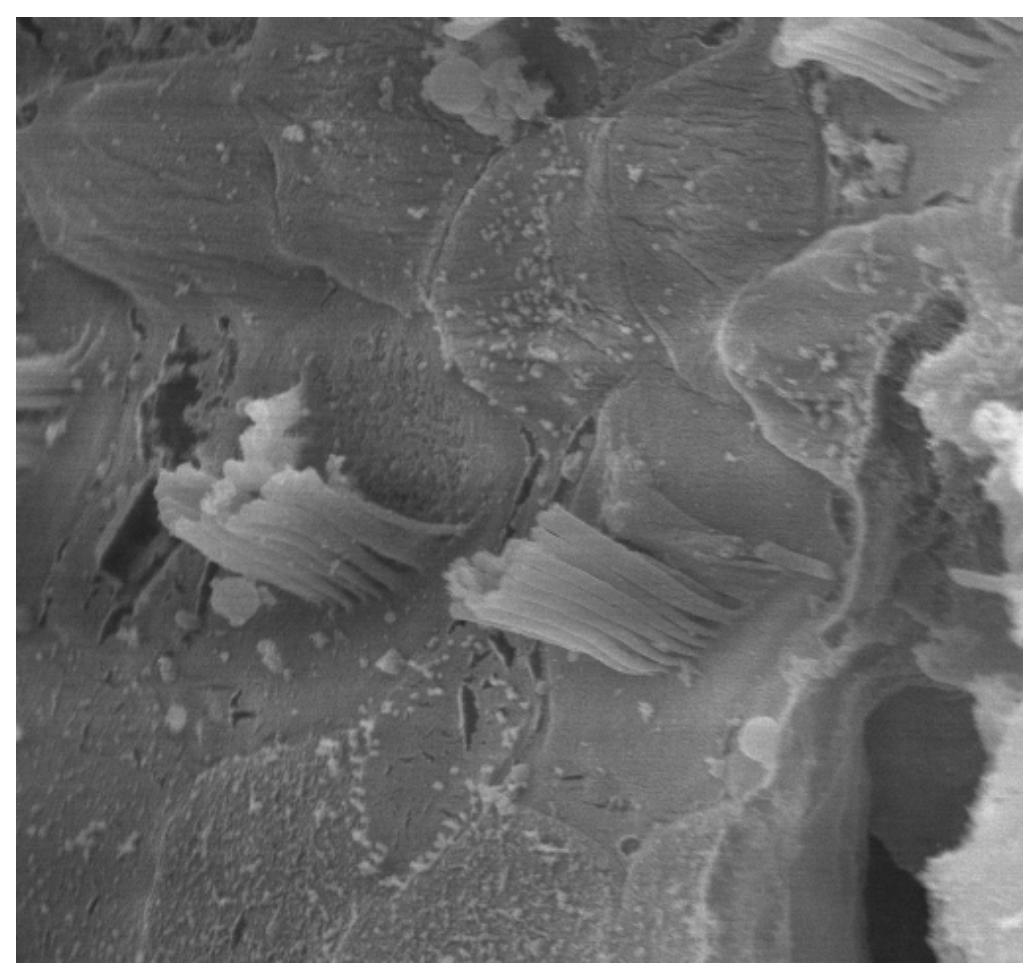

Figura 10 - Eletromicrografia de varredura da integridade das células ciliadas externas e de seus estereocílios da citoarquitetura da cóclea no animal $\mathrm{n}^{\mathrm{o}} 1$ do grupo Gc.

\subsubsection{Grupo EGb - Gegb}

Observou-se a manutenção da citoarquitetura coclear, assim como a integridade das células ciliadas externas e de seus estereocílios. Verificou-se a presença de hemácias livres no interior de vaso sanguíneo da cóclea. A Figura 11 mostra a eletromicrografia de varredura da citoarquitetura coclear na cobaia $n^{0} 8$ do grupo Gegb em microscopia eletrônica de varredura. 


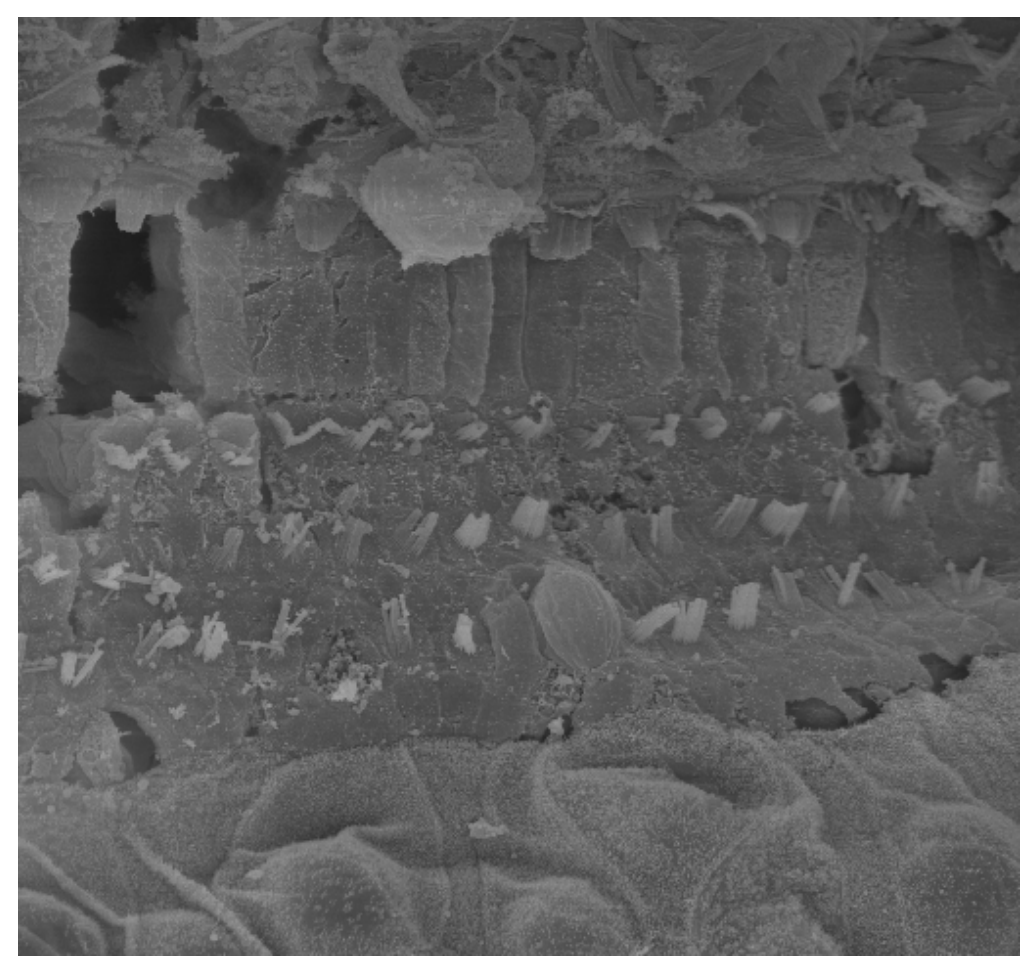

Figura 11 - Eletromicrografia de varredura da citoarquitetura coclear com manutenção das três fileiras de células ciliadas externas na cobaia $n^{\circ}$ 8 do grupo Gegb.

A Figura 12 mostra a eletromicrografia de varredura da integridade das células ciliadas externas da citoarquitetura da cóclea no animal $n^{\circ} 7$ do grupo Gegb em microscopia eletrônica de varredura. 


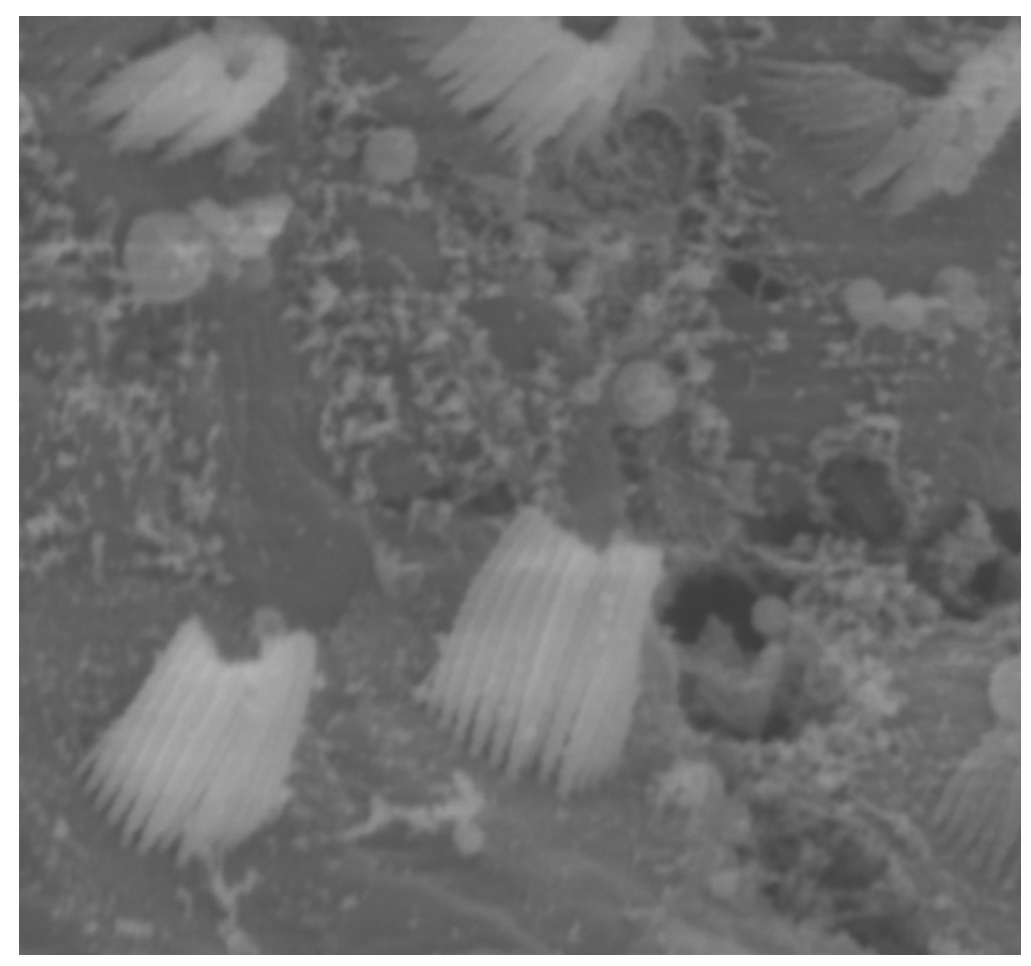

Figura 12 - Eletromicrografia de varredura da integridade das células ciliadas externas da citoarquitetura da cóclea no animal n ${ }^{\circ} 7$ do grupo Gegb.

A Figura 13 mostra a eletromicrografia de varredura da citoarquitetura da cóclea com presença de hemácias livres no interior de vaso sanguíneo coclear do animal $\mathrm{n}^{\circ}$ 7 do grupo Gegb. 


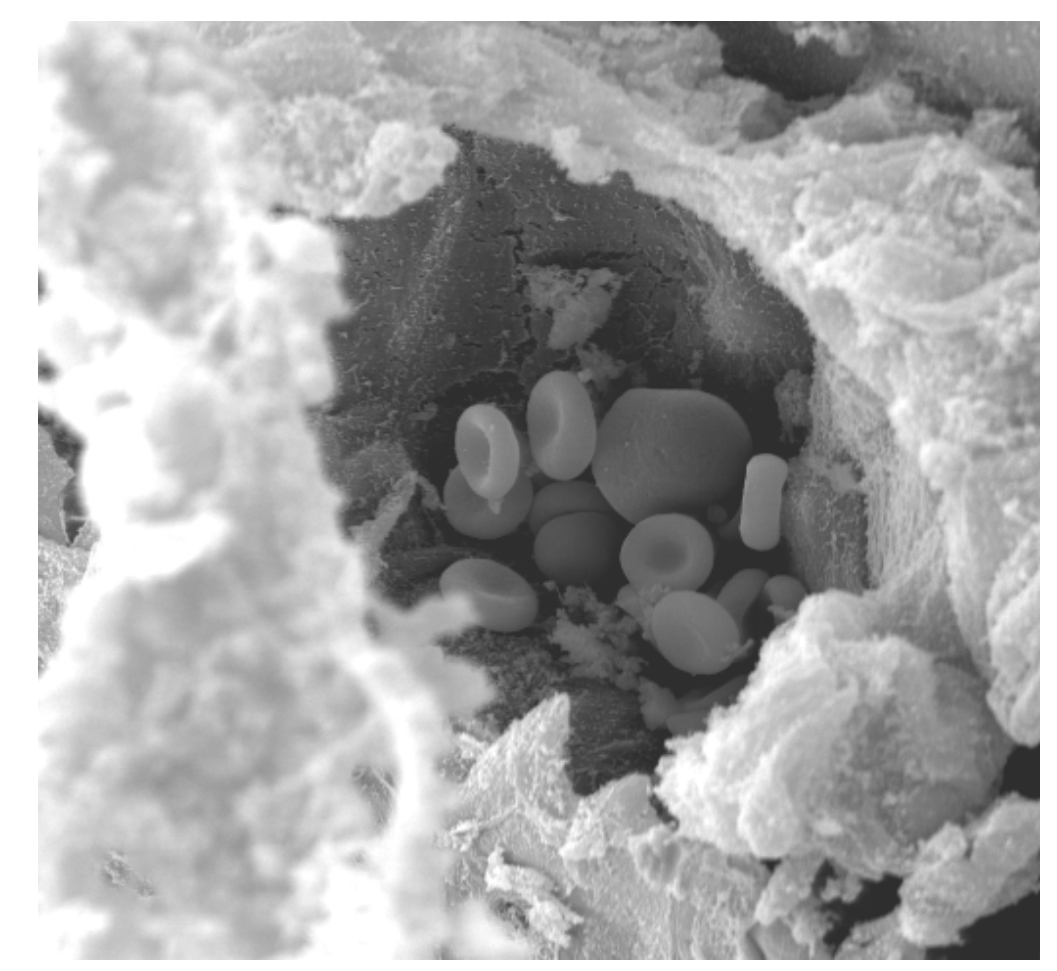

Figura 13 - Eletromicrografia de varredura da citoarquitetura da cóclea com presença de hemácias livres no interior de vaso sanguíneo coclear do animal $n^{\circ} 7$ do grupo Gegb.

\subsubsection{Grupo EGb com Ruído - Gegb+r}

Nas cobaias do grupo Gegb+r observou-se a manutenção da citoarquitetura coclear, com preservação das três fileiras de células ciliadas externas. Evidenciou-se edema e fusão de alguns grupos de estereocílios em meio a grupos normais. A Figura 14 mostra a eletromicrografia de varredura da citoarquitetura coclear da cobaia $n^{0} 10$ do grupo Gegb+r . 


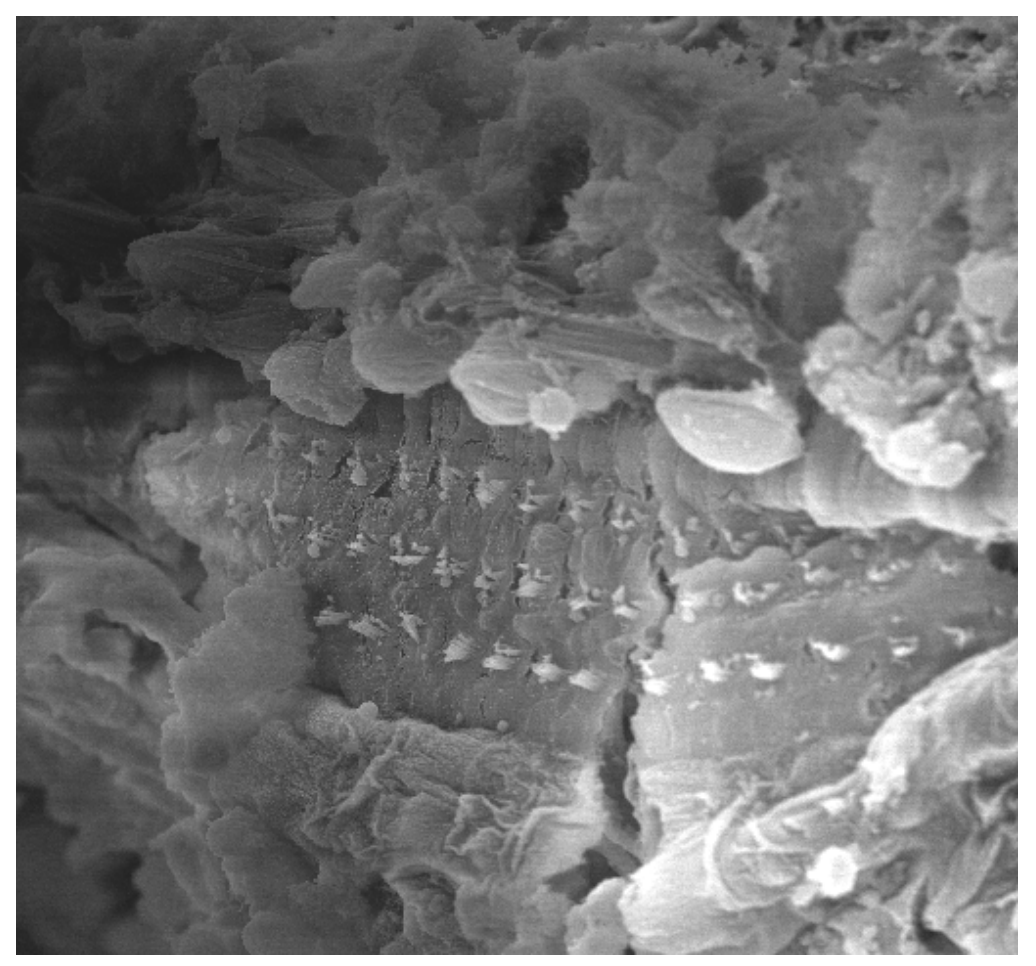

Figura 14 - Eletromicrografia de varredura da manutenção da citoarquitetura da cóclea de cobaia $\mathrm{n}^{\mathrm{o}} 10$ do grupo $\mathbf{G e g b + r}$, com a presença das três fileiras de células ciliadas externas.

A Figura 15 mostra a eletromicrografia de varredura da citoarquitetura coclear com edema e fusão ocasional de estereocílios na cobaia $\mathrm{n}^{\circ} 10$ do grupo $\mathbf{G e g b}+\mathbf{r}$ em microscopia eletrônica de varredura. 


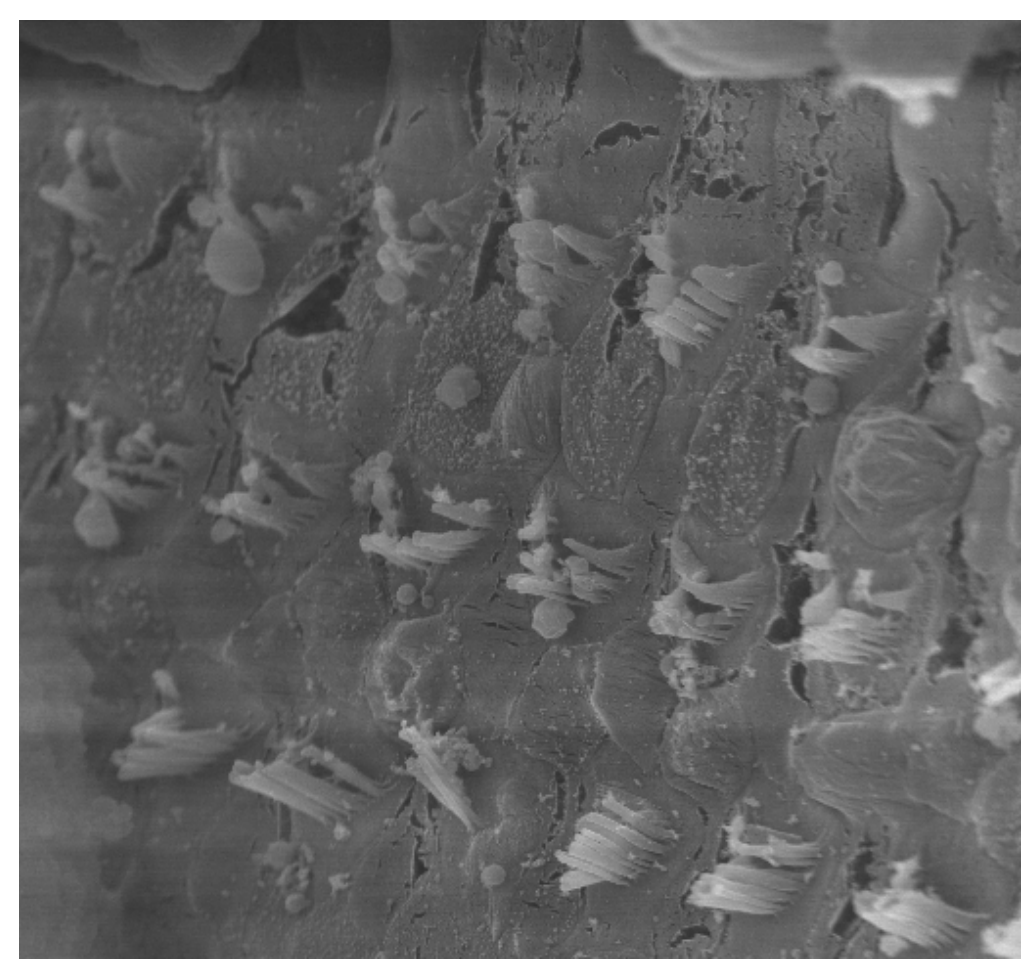

Figura 15 - Eletromicrografia de varredura da citoarquitetura coclear com edema e fusão ocasional de estereocílios na cobaia nº 10 do grupo Gegb+r .

\subsubsection{Grupo Ruído - Gr}

Nas cobaias do grupo Gr observou-se destruição das fileiras de células ciliadas externas, com alteração da citoarquitetura coclear, assim como vacuolização e edema celular, alongamento, fusão e quebra de estereocílios. A Figura 16 mostra a eletromicrografia de varredura da citoarquitetura coclear do animal $n^{0} 20$ do grupo Gr. 


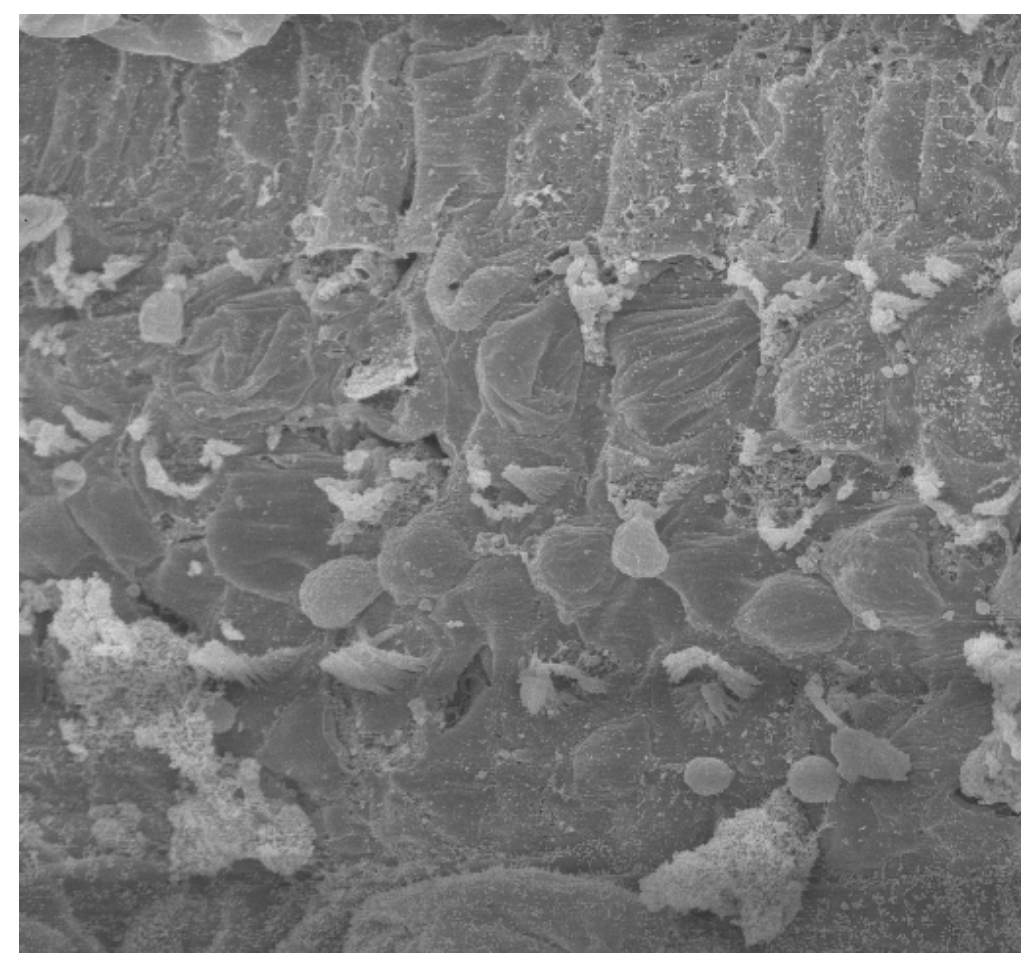

Figura 16 - Eletromicrografia de varredura da citoarquitetura coclear com ausência de células ciliadas, vacuolização e edema celulares, e quebra dos estereocílios na cobaia nº 20 do grupo Gr.

A Figura 17 mostra a eletromicrografia de varredura da citoarquitetura coclear com alongamento e fusão de estereocílios na cobaia $n^{0} 19$ do grupo $\mathbf{G r}$. 


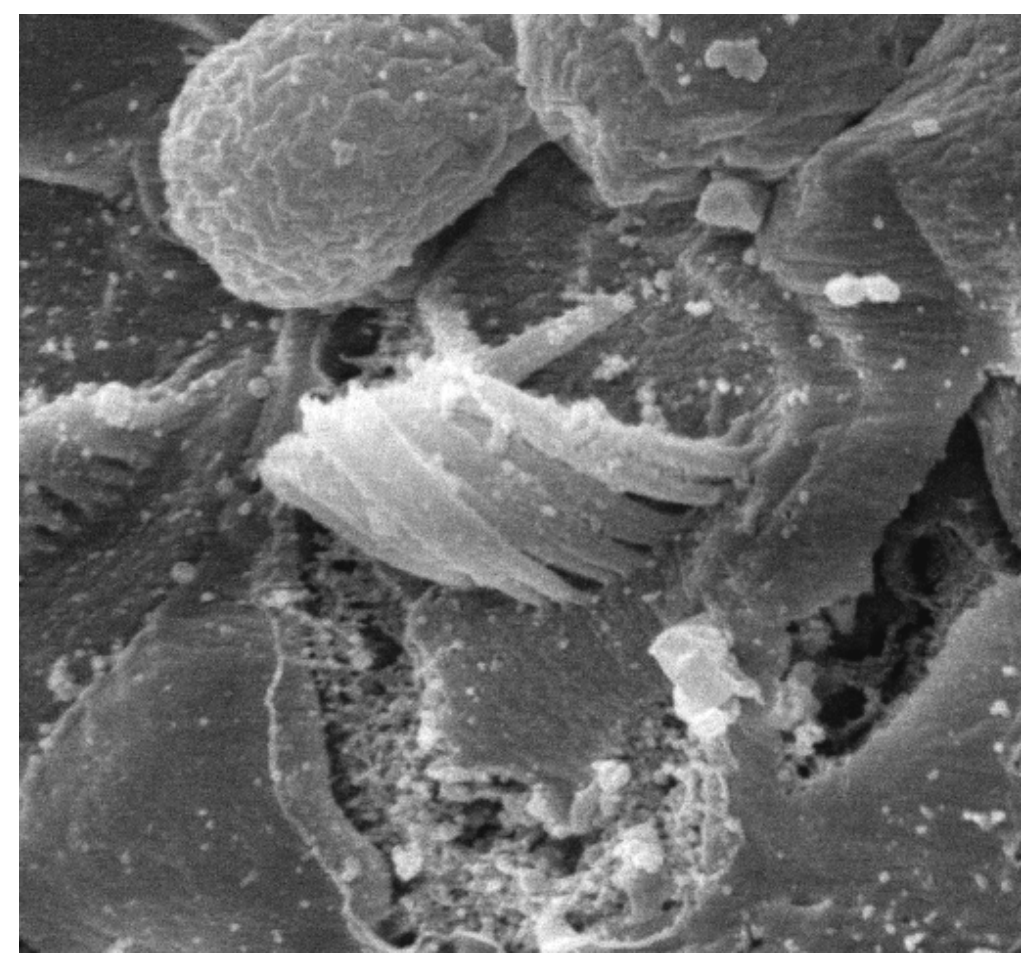

Figura 17 - Eletromicrografia de varredura da citoarquitetura coclear com alongamento e fusão de estereocílios na cobaia nº 19 do grupo Gr.

A Figura 18 mostra a eletromicrografia de varredura da citoarquitetura da cóclea com alongamento, fusão e aspecto estrelado dos estereocílios na cobaia $\mathrm{n}^{\mathrm{o}} 19$ do grupo Gr . 


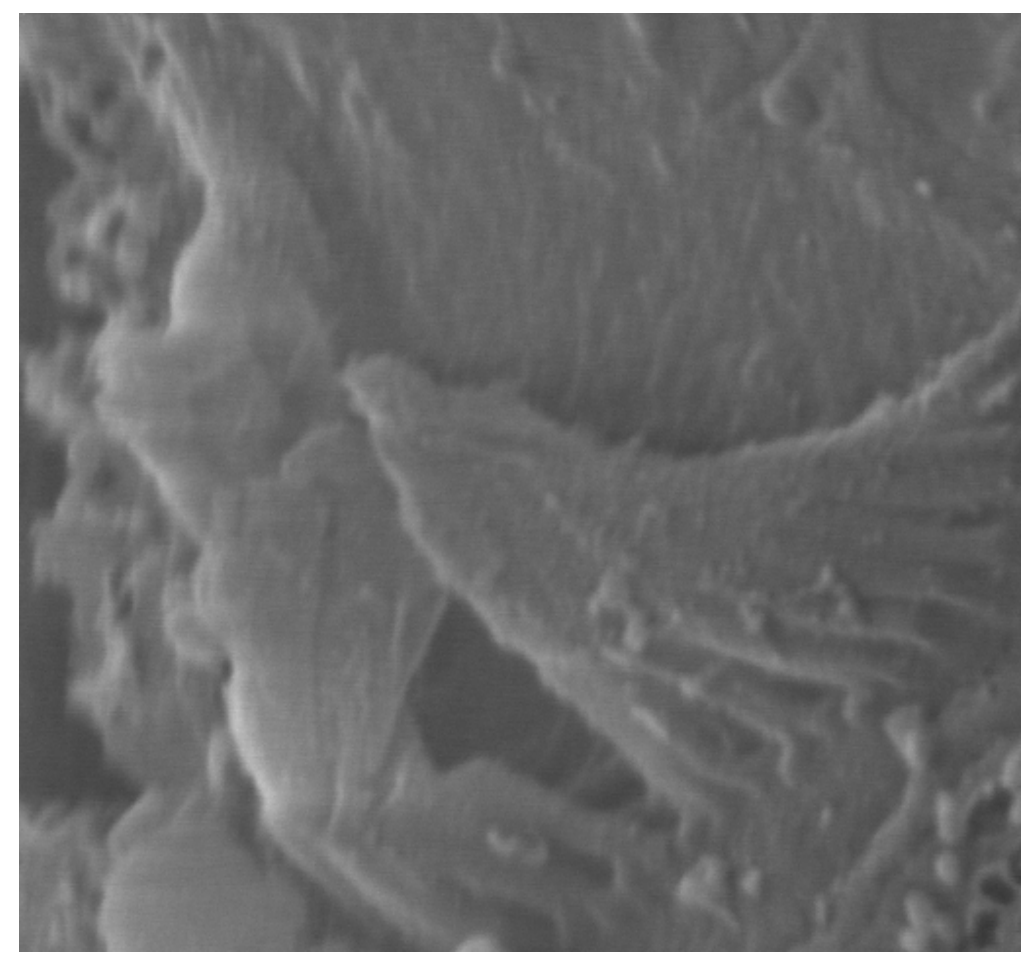

Figura 18 - Eletromicrografia de varredura da citoarquitetura da cóclea com alongamento, fusão e aspecto estrelado dos estereocílios na cobaia $n^{\circ} 19$ do grupo Gr. 
6. DISCUSSÃO 


\section{DISCUSSÃO}

\subsection{Delineamento da pesquisa}

Para que se possa iniciar a discussão desta pesquisa é importante ressaltar que o tema “prevenção da perda auditiva causada por nível elevado de pressão sonora” é objeto de grande interesse na comunidade de Volta Redonda, RJ, por ser um município com nível de ruído alto e cuja renda principal baseia-se na indústria metalúrgica.

Na minha vivência como otorrinolaringologista tenho constatado um grande número de pacientes com manifestações auditivas causadas pela exposição excessiva ao ruído. A perda auditiva sensorioneural é irreversível, porém, evitável e por este motivo decidiu-se buscar alternativas clínicas medicamentosas que permitissem a proteção da cóclea a ser submetida ao referido estímulo. Delineou-se, portanto, um trabalho experimental que pudesse mimetizar situações de risco auditivo por estímulo sonoro intenso, criando um laboratório experimental nas dependências físicas do Centro Universitário Fundação Oswaldo Aranha, UNIFOA, Volta Redonda, RJ. Com os resultados encontrados, espera-se contribuir para a prevenção da perda auditiva sensorioneural não só nos trabalhadores metalúrgicos, como 
também em todos os que, em seu dia a dia, submetem-se a níveis elevados de ruído no trabalho, no lazer e em seu meio ambiente.

O caráter experimental desta pesquisa permitiu a análise histológica da ação do extrato seco de Ginkgo biloba EGb 761 na arquitetura da cóclea exposta a nível elevado de pressão sonora, o que não poderia ser realizado em estudos clínicos.

A distribuição dos animais em quatro grupos possibilitou, pela comparação dos grupos Gr e Gegb+r, a avaliação da ação da droga utilizada na possível proteção da cóclea exposta ao estímulo sonoro intenso. O Gc foi submetido ao uso de solução fisiológica durante todo o tempo do estudo, nas mesmas condições que os demais grupos, permitindo avaliação comparativa das alterações ocorridas na arquitetura da cóclea dos grupos Gr e Gegb+r. O Gegb foi utilizado com o objetivo de avaliar a ação do extrato seco de Ginkgo biloba EGb 761, isoladamente, na cóclea.

\subsection{Animal de experimentação}

A escolha de cobaias para os testes foi em razão do grande número de trabalhos científicos em otologia realizados com guinea pig, assim como obtenção fácil em laboratórios de pesquisa, simplicidade na manutenção e manuseio, e pelo custo baixo. A anatomia da orelha da cobaia favorece os estudos otológicos. O acesso cirúrgico retro-auricular não apresenta grandes vasos sangüíneos ou músculos; a cápsula ótica é acessada rapidamente e retirada sem a necessidade de trepanação óssea. Animais com massa aproximada de 350 g apresentam menor incidência de 
infecções na orelha média (McCormick; Nuttal, 1976). Neste estudo, foram utilizados espécimes somente do sexo feminino, para uniformização da amostra. A seleção de cobaias albinas foi realizada de acordo com Lawrence (1973), que afirma que os limiares auditivos das mesmas são mais sensíveis do que os limiares das cobaias pigmentadas.

\subsection{Otoemissões Acústicas}

As OEA foram empregadas por constituírem método qualitativo eficaz na avaliação da vitalidade das células ciliadas externas, permitindo também a exclusão de alterações inflamatórias e infecciosas na orelha média (Khvoles et al., 1999). É um método amplamente usado na literatura, possibilitou a seleção dos animais no início do experimento e a verificação da capacidade lesiva do ruído utilizado, antes do sacrifício das cobaias.

Para a segunda aferição, no $34^{\circ}$ dia, aguardou-se 72 horas após a realização do estímulo sonoro, para evitar a recuperação da possível perda auditiva temporária (PTS). (Puel et al., 1998; Oliveira, 2001)

\subsection{Droga de estudo}

Com o conhecimento dos mecanismos fisiopatológicos da ação do ruído na cóclea, procurou-se uma substância que pudesse agir de forma a proteger as células ciliadas externas, os neurônios auditivos e os fenômenos vasomotores. 
O extrato seco de Ginkgo biloba EGb 761 foi utilizado por apresentar ação comprovada como trivasoregulador, influenciando todo o sistema circulatório e não somente o sistema arterial, venoso e capilar isoladamente, como afirma Charagnac, em 1976. Outras propriedades como: ação neuroprotetora, que causa o aumento do metabolismo energético cerebral; proteção contra hipóxia e isquemia; efeitos protetores e curativos no edema cerebral; efeitos nos sistemas colinérgicos centrais; redução das deficiências dos neurotransmissores por causa da idade; proteção contra lesões nas estruturas cerebrais; melhor adaptação ao estresse; assim como por suas ações hemorreológica e metabólica anti-oxidante (DeFeudis, 1998; Hyppolito et al.., 2003). Sua escolha também foi fundamentada em: larga utilização social, comum na população brasileira; facilidade de obtenção; custo acessível, diversas formas de apresentação no mercado (comprimidos e gotas); e, baixo porcentual de efeitos adversos, relatados na literatura, tanto no Homem quanto nos animais de experimentação.

\subsection{Estímulo sonoro}

Para a realização do estímulo sonoro intenso tomou-se o cuidado de utilizar câmara acústica semi-anecóica, que permitisse posicionar o animal com distribuição uniforme do ruído nas duas orelhas e que evitasse a dispersão do ruído para o ambiente externo, totalmente forrada por material de revestimento acústico. A câmara acústica utilizada não apresentava qualquer lateral com vidro que permitisse 
a verificação da intensidade do som em seu interior e a posição dos animais durante os trinta minutos de estímulo sonoro.

Para observar o nível de pressão sonora dentro do compartimento foi utilizado decibelímetro. A câmara fotográfica digital para fotografar os animais foi montada em tripé curto, com acionamento de temporizador e em posição oblíqua ao visor do mesmo decibelímetro usado para evitar o excesso de luz. Como a referida câmara acústica apresentava pouca entrada de ar, foi dada atenção à oxigenação dos animais. Com a orientação do médico veterinário, os animais foram mantidos durante os trinta minutos no interior da câmara, pois quando anestesiados possuem metabolismo basal que não necessita de aporte ventilatório excessivo, além de não terem sofrido resfriamento corporal por causa do ambiente fechado e forrado da câmara acústica. As condições clínicas apropriadas dos animais, após sua permanência no ambiente acústico, comprovaram a ausência de risco.

A potência sonora foi estipulada num mínimo de $120 \mathrm{~dB}$ e máximo de $122 \mathrm{~dB}$, de acordo com os experimentos de Engström e Ades (1960), Beagley (1965), Hawkins Jr (1971), Oliveira et al. (1980) e Puel et al. (1998), que descrevem alterações irreversíveis na citoarquitetura da cóclea a partir de 90 dB.

Deve-se verificar a tensão de saída na rede elétrica local antes do estímulo sonoro, pois se a mesma estiver acima de $10 \mathrm{~V}$ a sirene não terá vida útil suficiente para a execução do experimento. Para evitar danos ao equipamento, a voltagem da sirene 
foi fixada em $220 \mathrm{~V}$, apesar da voltagem na rede ser $110 \mathrm{~V}$, o que reduziu a tensão de uso na mesma para valores inferiores a $10 \mathrm{~V}$.

O tempo estipulado em trinta minutos para a ação do ruído sobre os animais mostrou eficácia no potencial lesivo, como pode ser verificado na análise histológica realizada. (Beagley, 1965)

\subsection{Avaliação da citoarquitetura celular dos grupos estudados}

Após a análise dos resultados obtidos, verificou-se a congestão capilar na estria vascular (Tabela 1) e hemorragia (Tabela 4) na cóclea das cobaias do grupo Gegb. Essas alterações não foram encontradas no Gc, o que mostra a atuação hemodinâmica do extrato seco de Ginkgo biloba EGb 761, de acordo com os relatos de Charagnac (1976), Dubreil (1986) e Clostre (1986). Todas as cobaias submetidas ao uso oral do extrato seco de Ginkgo biloba EGb 761, Gegb, apresentaram congestão capilar acentuada na estria vascular, e 75\% delas hemorragia discreta. A razão de verossimilhança foi estatisticamente significante, na qual $\mathrm{p}=0,001$ e $\mathrm{p}=$ 0,014 respectivamente, comprovando a atuação da droga na irrigação da cóclea.

O extrato seco de Ginkgo biloba EGb 761 mostrou ser uma droga segura durante o estudo, não foi constatada perda da amostra ou comprometimento da saúde dos animais estudados. Em relação à sua ação na citoarquitetura do órgão de Corti e na membrana vestibular de cobaias, não submetidas ao ruído, não foi possível 
documentar alterações, o que permite inferir que a droga não causou danos estruturais ao tecido coclear.

As OEA foram realizadas inicialmente para a verificação da vitalidade e funcionalidade das células ciliadas externas, alvo da ação deletéria de níveis elevados de pressão sonora (Dagli; Canlon, 1997). Os grupos submetidos ao estímulo sonoro intenso, Gegb+r e Gr, apresentaram ausência das OEA, enquanto os grupos não submetidos ao ruído, Gc e Gegb, preservaram-nas. Esse fato demonstra qualitativamente a ação do ruído sobre as células ciliadas externas, não permitindo, porém, a partir dessa observação, avaliar quantitativamente a preservação funcional obtida com a droga ou a lesão causada pelo estímulo sonoro. As OEA não foram um bom instrumento de quantificação da função coclear nesta situação específica, não sendo possível comparar alterações sutis de limiares acústicos pré e pós-estímulo sonoro pelo método. Os métodos histológicos na avaliação estrutural das cócleas foram mais efetivos, não havendo correspondência funcional com os achados das OEA após estímulo sonoro intenso. Talvez a quantificação funcional da audição das cobaias fosse possível com a audiometria de tronco encefálico com pesquisa de freqüências isoladas ou da eletrococleografia.

Ao analisar conjuntamente os grupos Gc, Gegb+r e Gr, foram observadas diferenças estatisticamente significantes entre o $\mathbf{G c}$ e os grupos $\mathbf{G e g b}+\mathbf{r}$ e $\mathbf{G r}$ nos parâmetros analisados à microscopia de luz (Tabelas 5, 6, 7 e 8), porque os animais do grupo Gc não apresentaram alterações em quaisquer dos parâmetros avaliados. Ao agrupar os critérios congestão capilar na estria vascular (Tabela 5) e hemorragia 
(Tabela 8) verificou-se que o grupo Gr apresentou congestão acentuada em 71,4\% e hemorragia acentuada em $37,5 \%$ dos animais, ao passo que no grupo $\mathbf{G e g b}+\mathbf{r}$ a congestão acentuada foi observada em 12,5\% e a hemorragia acentuada em 62,5\% dos animais. Entendendo-se congestão capilar como fenômeno causado pela vasoconstricção e aglomeração de hemácias, e hemorragia como extravasamento sanguíneo do leito vascular, (Bueno, 1983), verificou-se que a ação do ruído sem a prévia utilização do extrato seco de Ginkgo biloba EGb 761, Gr, foi capaz de gerar maior constricção vascular e congestão intraluminal. Certamente essas alterações circulatórias resultaram em menor aporte sanguíneo às cócleas estudadas, enquanto o grupo Gegb+r, contrariamente, apresentou menor constricção capilar e maior fluxo sanguíneo, o que coincide com os relatos de Hawkins Jr, em 1971. Apesar dos cálculos estatísticos não apresentarem relevância entre os resultados dos grupos Gr e Gegb+r, não se pode desprezar os achados citados, que testemunham a ação hemodinâmica e antiagregadora plaquetária da droga estudada.

Comparando-se os critérios “alterações do Órgão de Corti” (Tabela 6) e “alterações da membrana vestibular” (Tabela 7) à visualização sob microscopia de luz dos grupos Gc, Gr e Gegb+r, observa-se alterações discretas e degeneração do Órgão de Corti em 50\% dos animais do Gc e sua destruição em 100\% da amostra nos grupos Gr e Gegb+r. A ausência de alterações da membrana vestibular foi documentada em 75\% do grupo Gc e destruição celular em $87,5 \%$ dos animais dos grupos Gr e Gegb+r. Estes resultados demonstram que embora o Gc tenha apresentado diferenças na citoarquitetura coclear, que poderiam ser explicadas pela técnica de preparo, mostrou diferença estatisticamente significante em comparação 
com os grupos Gr e Gegb+r, fato que evidencia a lesão mecânica nas estruturas cocleares sob ruído intenso. O uso prévio do extrato seco de Ginkgo biloba EGb 761 não foi capaz, por esta técnica, de preservar os elementos analisados. Este fato justifica e prioriza a realização da MEV no estudo das possíveis diferenças estruturais entre as cócleas expostas ou não ao nível elevado de pressão sonora.

As imagens da MEV permitiram observar, no grupo Gegb+r, a manutenção da citoarquitetura coclear, com preservação das três fileiras de células ciliadas externas, apesar do aspecto vacuolizado e do edema de algumas células, da fusão ocasional e alongamento de estereocílios. O mesmo não ocorreu no grupo que foi exposto ao ruído e não recebeu a droga, $\mathbf{G r}$, no qual foram observados: edema de células ciliadas externas, com acúmulo de massas de cromatina que aumentam o diâmetro das mesmas; desarranjo dos estereocílios ou até degeneração completa, com a presença de algumas células intactas; fusão e alongamento de vários estereocílios; e a vacuolização do citoplasma celular, conferindo aspecto globular às células do Órgão de Corti. Esses achados coincidem com as descrições de Engström e Ades (1960), Beagley (1965), Bredberg (1970) e de Hawkins Jr (1971).

O preparo ideal das cócleas para microscopia de luz, segundo orientações recebidas, deveria ser feito com a perfusão dos animais com o fixador (formol 10\% tamponado) via veia jugular, antes do seu sacrifício, com a finalidade de preservar sua estrutura original. Certamente a qualidade dos cortes seria melhor, no entanto a proposta previu o estudo das orelhas direitas com microscopia de luz e das orelhas esquerdas com microscopia eletrônica, que inviabiliza tal técnica de preparo, pois a 
MEV prevê outros tipos de fixadores. O ideal, portanto, seria analisar os animais com apenas uma técnica histológica: ou microscopia de luz, ou microscopia eletrônica.

A prevalência, a irreversibilidade e o custo sócio-econômico da PAINPS motivaram a realização deste estudo. Ao finalizá-lo, obteve-se resultados que permitem que se continue acreditando que a pesquisa científica deva persistir na busca de opções farmacológicas que possam proteger o indivíduo das conseqüências nefastas que o ruído pode provocar. Certamente o progresso vem aliado a essas descobertas, vitais para o desenvolvimento saudável do Homem. 
7. CONCLUSÕES 


\section{CONCLUSÕES}

Os resultados obtidos neste trabalho permitem concluir:

1. Que na microscopia de luz pode-se observar:

O efeito do ruído no epitélio sensitivo da cóclea,

a. pelas alterações da membrana vestibular e órgão de Corti, significantemente mais freqüentes nos grupos Gr e Gegb+r em relação ao Gc;

b. presença significante de hemorragia nos grupos $\mathbf{G r}$ e $\mathbf{G e g b}+\mathbf{r}$, quando comparada ao Gc.

O efeito do extrato seco de Ginkgo biloba EGb 761 na cóclea,

a. pelo aumento significante da congestão vascular nas cobaias tratadas exclusivamente com a droga, Gegb, quando relacionado ao Gc;

b. pela diferença significante observada no grau de congestão vascular nos diversos grupos: leve no Gc, discreta no Gr e moderada no Gegb+r.

Não foi possível demonstrar diferença significante na citoarquitetura da cóclea entre os animais expostos ao ruído e que receberam ou não o extrato seco de Ginkgo biloba EGb 761. 
2. Que pelas imagens da Microscopia Eletrônica de Varredura pode-se ver que:

a. os dois grupos submetidos ao ruído, Gr e $\mathbf{G e g b + r}$, apresentaram lesões estruturais das células ciliadas e de sustentação;

b. as lesões observadas nos animais expostos ao ruído foram menos intensas no Gegb+r, levantando-se a hipótese de um possível efeito protetor do extrato seco de Ginkgo biloba EGb 761. 
7. REFERÊNCIAS 


\section{REFERÊNCIAS ${ }^{1}$}

Beagley HA. Acoustic trauma in the guinea pig. II. Electron microscopy including the morphology of cell junctions in the organ of Corti. Acta Otolaryngol. 1965 Dec; 60(6):479-95.

Bredberg G, Lindeman HH, Ades HW, West R, Engström H. Scanning Electron Microscopy of the Organ of Corti. Science. 1970; 170(960):861-3.

Bueno FS. Dicionário Escolar da Língua Portuguesa. 11ª ed. Rio de Janeiro: Ministério da Educação e Cultura, Fundação Nacional de Material Escolar; 1983.

Charagnac JL. La Trivasoregulation: Étude d'un trivasorégulateur: l'extract de Ginkgo biloba. Doctoral Thesis, Bichat-Beujon, Paris, 1976.

Clostre F. L’organisme aux membranes cellulaires: les différents niveaux d'actions pharmacologiques de l'extrait du Ginkgo biloba. Presse Med. 1986 Sep 25;15(31):152938.

Dagli S, Canlon B. The effect of Repeated Daily Noise Exposure on Sound-Conditioned and Unconditioned Guinea pigs. Hear. Res. 1997;104(1-2):39-46.

\footnotetext{
${ }^{1}$ Esta tese está de acordo com:

Referências: adaptado de International Committee of Medical Journal Editors (Vancouver)

Universidade de São Paulo. Faculdade de Medicina. Serviço de biblioteca e Documentação. Guia de apresentação de dissertações, teses e monografias. Elaborado por Anneliese Carneiro da Cunha, Maria Julia de A.L. Freddi, Maria F. Crestana, Marinalva de Souza Aragão, Suely Campos Cardoso, Valéria Vilhena. São Paulo: Serviço de Biblioteca e Documentação; 2004.

Abreviaturas dos títulos dos periódicos de acordo com List of Journals Indexed in Index Medicus.
} 
DeFeudis FV. Ginkgo biloba extract (EGb 761) from chemistry to the clinic. Wiesbaden, Ullstein Medical; 1998.

Dubreil, C. Essai thérapeutique dans les surdités cochléaires aiguées. La Presse Médicale. 1986 ;15(31) :1559-61.

Engström H, Ades HW. Effect of high-intensity noise on inner ear sensory epithelia. Acta Otolaryngol. 1960; Suppl 158:219-29.

Hawkins JR, J.E. The Role of Vasoconstriction in Noise-Induced Hearing Loss. Annals Oto Rhinol Laryngol. 1971; 80(6): 902 - 13.

Hyppolito MA, Oliveira JAA, Rossato M. Holanda F. Ototoxicidade da cisplatina e otoproteção pelo extrato de Ginkgo biloba às células ciliadas externas: estudo anatômico e eletrofisiológico. Rev Bras Otorrinolaringol. 2003 jul-ago;69(4):504-11.

Jastreboff PJ, Zhou S, Jastreboff M.M, Kwapis, U, Gryczynska U. Attenuation of salicylate-induced tinnitus by Ginkgo biloba extract in rats. Audiol. Neurootol. 1997; 2:197-212.

Khvoles R, Freeman S, Sohmer H. Transient Evoked Otoacoustic Emissions in Laboratory Animals. Audiology. 1999 May-Jun;38(3):121-6.

Lawrence, M. Acute overpressure and chronic noise injury. Prac. Med. 1973; 9:1-21. 
Lynch ED, Gu R, Pierce C, Kil J. Ebselen-mediated protection from single and repeated noise exposure in rat. Laryngoscope. 2004 Feb;114(2):333-7.

McCormick JG, Nuttall AL. Auditory Research. In: Wagner JE, Manning PJ. The Biology of the Guinea Pig. New York, San Francisco, London: Academic Press. Cap 19, 1976, p.281-301.

Ministério da Saúde, Brasil, Norma regulamentadora 15. Limites de tolerância para ruído contínuo ou intermitente. Portaria $\mathrm{n}^{0}$ 3.214, de 08 de junho de 1978. In: Segurança e Medicina do Trabalho, v.16, pág. 123-34, São Paulo: Atlas, 1998.

Nudelmann AA, Costa EA, Seligman J, Ibáñez RN. Perda Auditiva Induzida pelo Ruído. Rio de Janeiro: Editora Revinter; v. II, 2001.

Oliveira JAA, Campagno LT, Ciclini GA, Andrade MH. Recuperação auditiva e alterações cocleares de cobaias expostas a ruído com experimentos agudos e crônicos. Rev Bras Otorrinolaringol. 1980 mai-ago; 46(2): 113-26.

Oliveira JAA. Prevenção e Proteção Contra Perda Auditiva Induzida por Ruído. In: Nudelmann AA, Costa EA, Seligman J, Ibañez RN. PAIR - Perda Auditiva Induzida pelo Ruído. Rio de Janeiro: Revinter; 2001. Vol.II:17-44.

Puel JL, Ruel J, Gervais D’Aldin C, Pujol R. Excitotoxicity and Repair of Cochlear Synapses After Noise Trauma Induced Hearing Loss. Neuroreport. 1998; 9:2109-14. 
National Institute for Occupational Safety and Health. Position statement - preventing noise-induced occupational hearing loss. 2003 oct. Available from: http://www.cdc.gov/niosh

Renon P. Treatment of acute cochlear deafness with Ginkgo biloba extrais (EGb 761) and hyperbaric oxygen therapy. Revue Otoneurophtalmol. 1993;26:29-33.

Seidman M, Babu S, Tang W, Naem E, Quirk WS. Effects of resveratrol on acoustic trauma. Otolaryngol Head Neck Surg. 2003 Nov;129(5):463-70.

Silveira, M. Preparo de Amostras Biológicas para Microscopia Eletrônica de Varredura. In: Souza W, Haddad AS, Attias M, Farina M, Meirelles MN, Silveira M, Benchimol M, Soares MJ, Barth OM, Machado RD, Souto-Padrón T. Técnicas Básicas de Microscopia Eletrônica Aplicadas às Ciências Biológicas. Rio de Janeiro: Sociedade Brasileira de Microscopia. 1998:33 - 44.

The National Institute of Health Available from: http://www.nih.gov 


\section{BIBLIOGRAFIA CONSULTADA}




\section{BIBLIOGRAFIA CONSULTADA ${ }^{2}$}

Comitê Nacional de Ruído E Conservação Auditiva. Perda auditiva pelo ruído relacionado ao trabalho. Documentos do Comitê. Boletim n. 1. São Paulo, 29/06/1994.

Junqueira LCU, Junqueira MMS. Técnicas Básicas de Histologia. São Paulo, Ed. Santos, 1983.

Marovitz WF, Arenberg IK, Thalmann R. Evaluation of Preparative Techniques for the Scanning Electron Microscope. Laryngoscope. 1970;80 (11):1680 - 1700.

Ministério da Saúde, Brasil, Norma regulamentadora 15. Limites de tolerância para ruído contínuo ou intermitente. Portaria $\mathrm{n}^{0}$ 3.214, de 08 de junho de 1978. In: Segurança e Medicina do Trabalho. São Paulo: Atlas. 1998; 16:123-34.

Naspitz J. Princípios de Anestesia em Alguns Animais de Laboratório. São Paulo. Separata. 15 pág.

\footnotetext{
${ }^{2}$ Esta tese está de acordo com: Referências: adaptado de International Committee of Medical Journal Editors (Vancouver) Universidade de São Paulo. Faculdade de Medicina. Serviço de biblioteca e Documentação. Guia de apresentação de dissertações, teses e monografias. Elaborado por Anneliese Carneiro da Cunha, Maria Julia de A.L. Freddi, Maria F. Crestana, Marinalva de Souza Aragão, Suely Campos Cardoso, Valéria Vilhena. São Paulo: Serviço de Biblioteca e Documentação; 2004. Abreviaturas dos títulos dos periódicos de acordo com List of Journals Indexed in Index Medicus.
} 
Oliveira JAA. Fisiologia Clínica da Audição - Cóclea Ativa. In: Nudelmann AA, Costa EA, Seligman J, Ibañez RN. PAIR - Perda Auditiva Induzida pelo Ruído. Porto Alegre, Bagaggem Comunicação Ltda, 1997. pág. 101- 42.

Oliveira JAA. O Mecanismo Eletrobiomecânico Ativo da Cóclea. Rev Bras Otorrinolaringol. 1993; 59(4):2414 - 27.

Oliveira JAA, Marseillan RF. Estudo de lesões cocleares pela Técnica de Preparações de Superfície na Cobaia. Rev Bras Otorrinolaringol. 1971 jan-abr; 37(1): 2-5.

Thorne PR, Gavin, JB, Herdson PB. A Quantitative Study of the Sequence of Topographical Changes in the Organ of Corti Following Acoustic Trauma. Acta Otolaryngol. (Stockh), 1984; 97:69-81.

Voldrich L. Experimental Acoustic Trauma. Part I. Acta Oto-Laryngologica. 1972; 74(6):392 - 7. 